\title{
The challenge of reconciling bottom-up agricultural methane emissions inventories with top-down measurements
}

\author{
R.L. Desjardins ${ }^{\mathrm{a}, *}$, D.E. Worth ${ }^{\mathrm{a}}$, E. Pattey ${ }^{\mathrm{a}}$, A. VanderZaag ${ }^{\mathrm{a}}$, R. Srinivasan ${ }^{\mathrm{b}}$, M. Mauder ${ }^{\mathrm{c}}$, \\ D. Worthy ${ }^{\mathrm{d}}$, C. Sweeney ${ }^{\mathrm{e}}$, S. Metzger ${ }^{\mathrm{f}}$ \\ a Science and Technology Branch, Agriculture and Agri-Food Canada, 960 Carling Avenue, Ottawa, ON, Canada \\ b National Research Council Canada, Aerospace, Flight Research Laboratory, 1920 Research Road, Ottawa, ON, Canada \\ ${ }^{c}$ Karlsruhe Institute of Technology (KIT) Institute of Meteorology and Climate Research (IMK-IFU), Kreuzeckbahnstr. 19, 82467, Garmisch-Partenkirchen, Germany \\ d Environment and Climate Change Canada, Climate Chemistry Measurements and Research, Toronto, ON, Canada \\ e National Oceanic and Atmospheric Administration (NOAA), R/GMD1, Boulder, CO, 80305, USA \\ ${ }^{\mathrm{f}}$ Battelle Ecology, NEON Project,1685 38th St., Ste. 100, Boulder, CO, 80301, USA
}

Keywords:

Eddy covariance

Trace gas flux

Relaxed eddy accumulation

Wavelet analysis

$\mathrm{CH}_{4}$ sensor

Farm

Wetlands

\section{A B S T R A C T}

Agriculture is estimated to produce more than $40 \%$ of anthropogenic methane $\left(\mathrm{CH}_{4}\right)$ emissions, contributing to global climate change. Bottom-up, IPCC based methodologies are typically used to estimate the agriculture sector's contribution, but these estimates are rarely verified beyond the farm gate, due to the challenge of separating interspersed sources. We present flux measurements of $\mathrm{CH}_{4}$, using eddy covariance (EC), relaxed eddy accumulation (REA) and wavelet covariance obtained using an aircraft-based measurement platform and compare these top-down estimates with bottom-up footprint adjusted inventory estimates of $\mathrm{CH}_{4}$ emissions for an agricultural region in eastern Ontario, Canada. Top-down $\mathrm{CH}_{4}$ fluxes agree well (mean \pm 1 standard error: $\mathrm{EC}=17 \pm 4 \mathrm{mg}$ $\mathrm{CH}_{4} \mathrm{~m}^{-2} \mathrm{~d}^{-1} ; \mathrm{REA}=19 \pm 3 \mathrm{mg} \mathrm{CH}_{4} \mathrm{~m}^{-2} \mathrm{~d}^{-1}$, wavelet covariance $=16 \pm 3 \mathrm{mg} \mathrm{CH}_{4} \mathrm{~m}^{-2} \mathrm{~d}^{-1}$ ), and are not statistically different, but significantly exceed bottom-up inventory estimates of $\mathrm{CH}_{4}$ emissions based on animal husbandry ( $8 \pm 1 \mathrm{mg} \mathrm{CH}_{4} \mathrm{~m}^{-2} \mathrm{~d}^{-1}$ ). The discrepancy between top-down and bottom-up estimates was found to be related to both increasing fractional area of wetlands in the flux footprint, and increasing surface temperature. For the case when the wetland area in the flux footprint was less than $10 \%$ fractional coverage, the top-down and bottom-up estimates were within the measurement error. This result provides the first independent verification of agricultural methane emissions inventories at the regional scale. Wavelet analysis, which provides spatially resolved fluxes, was used to attempt to separate $\mathrm{CH}_{4}$ emissions from managed and unmanaged $\mathrm{CH}_{4}$ sources. Opportunities to minimize the challenges of verifying agricultural $\mathrm{CH}_{4}$ emissions inventories using aircraft flux measuring systems are discussed.

\section{Introduction}

Methane $\left(\mathrm{CH}_{4}\right)$ is the second most important greenhouse gas (GHG) after carbon dioxide $\left(\mathrm{CO}_{2}\right)$, and contributes about $20 \%$ of the global radiative forcing due to GHGs (Kirschke et al., 2013). Its atmospheric concentration has increased by more than $150 \%$ since 1750 . There are many sources of $\mathrm{CH}_{4}$ in the terrestrial biosphere. Global $\mathrm{CH}_{4}$ sources, which include unmanaged and managed sources, have been estimated at $678 \mathrm{Tg} \mathrm{CH}_{4} \mathrm{yr}^{-1}$ with a range of 542852 for the 20002009 decade. Wetlands are the main unmanaged source and they account for $217 \mathrm{Tg} \mathrm{CH}_{4} \mathrm{yr}^{-1}$ of global $\mathrm{CH}_{4}$ emissions (IPCC, 2013). Managed sources originate primarily from fossil fuels $\left(96 \mathrm{Tg} \mathrm{CH}_{4} \mathrm{yr}^{-1}\right.$ ), rumi nants $\left(89 \mathrm{Tg} \mathrm{CH}_{4} \mathrm{yr}^{-1}\right)$, landfill/waste $\left(75 \mathrm{Tg} \mathrm{CH}_{4} \mathrm{yr}^{-1}\right)$, rice
(36 $\mathrm{Tg} \mathrm{CH}_{4} \mathrm{yr}^{-1}$ ) and biomass burning (35 $\mathrm{Tg} \mathrm{CH}_{4} \mathrm{yr}^{-1}$ ) (IPCC, 2013). There are very large uncertainties in these estimates. In Canada, emissions from wetlands range from 16 to $29 \mathrm{Tg} \mathrm{CH}_{4} \mathrm{yr}^{-1}$ depending on the study (Thompson et al., 2017). Agriculture accounts for about $1.4 \mathrm{Tg} \mathrm{CH}_{4} \mathrm{yr}^{-1}$, approximately $88 \%$ are from enteric fermentation and the remaining $12 \%$ are from manure management systems (Environment Canada, 2015b; Karimi Zindashty et al., 2012). Little is known about the magnitude of the $\mathrm{CH}_{4}$ emissions from wetlands within the agricultural landscape.

Canada employs an Intergovernmental Panel on Climate Change (IPCC, 2006) Tier II methodology to estimate agricultural $\mathrm{CH}_{4}$ emis sions, which in its simplest form is the product of emission factors (EFs) and activity data (e.g. animal population). Country specific emission

\footnotetext{
* Corresponding author.

E-mail address: ray.desjardins@agr.gc.ca (R.L. Desjardins).
} 
factors are typically obtained by either confining a small number of animals in a chamber (Beauchemin and McGinn, 2005; Beauchemin and McGinn, 2006), or in instrumented barns (Kinsman et al., 1995; Sauer et al., 1998) or by inferring $\mathrm{CH}_{4}$ emissions through atmospheric measurements (Flesch et al., 2013) from cattle on pasture (Felber et al., 2015), in pens (McGinn et al., 2009), in feedlots (van Haarlem et al., 2008) or in barns (Gao et al., 2010; VanderZaag et al., 2014).

Several methods have been used to obtain and evaluate $\mathrm{CH}_{4}$ emis sion estimates. Denmead et al. (2000) used mass balance flux gradient measurements of $\mathrm{CH}_{4}$ to verify IPCC inventory estimates of $\mathrm{CH}_{4}$ emis sions from an extensive grazing area in New South Wales. Judd et al. (1999) obtained comparable estimates of $\mathrm{CH}_{4}$ emissions from a flock of sheep using half hourly averages from a flux gradient technique and measurements from individual sheep based on a sulphur hexafluoride tracer technique. Diurnal variations of $\mathrm{CH}_{4}$ and $\mathrm{CO}$ mixing ratios were used by Hsu et al. (2010) to estimate $\mathrm{CH}_{4}$ emissions using well docu mented $\mathrm{CO}$ emissions. With this relationship a top down $\mathrm{CH}_{4}$ emissions inventory was calculated for Los Angeles County which was then compared with bottom up $\mathrm{CH}_{4}$ emissions inventory based on IPCC methodologies.

Obtaining accurate $\mathrm{CH}_{4}$ emission estimates for different sources in a region is challenging. There have been a number of inverse modelling studies focusing on Europe (Bergamaschi et al., 2010; Cressot et al., 2014; Manning et al., 2011) and on the United States (Kort et al., 2008; Miller et al., 2013; Zhao et al., 2009). Large discrepancies were found in both the spatial distributions and flux estimates amongst these studies (Miller et al., 2013; Vogel et al., 2012). This is primarily related to the differences in the modelling approaches (e.g., different atmospheric transport models, optimization methods, etc.). Inversion modelling is also not capable of distinguishing interspersed sources from different sectors. Overlapping grid level sources from different sectors are typi cally grouped and treated as a single source. Atmospheric observations from greenhouse gas monitoring satellites such as GOSAT (Turner et al., 2015) and TROPOMI (Veefkind et al., 2012) are not likely to be useful to separate the contributions of managed and unmanaged $\mathrm{CH}_{4}$ sources because of their coarse spatial resolution and their lack of sensitivity. Bottom up emission estimates based on IPCC methodologies, which are used for UNFCCC reporting, poorly account for animal types, man agement practices and climate. Top down $\mathrm{CH}_{4}$ emission estimates have frequently been reported as being substantially higher than bottom up estimates (Turner et al., 2015). This discrepancy points to the im portance of being able to quantify the contribution of $\mathrm{CH}_{4}$ sources at a wide range of scales.

Top down measurement approaches that incorporate emissions from tens to hundreds of $\mathrm{km}^{2}$ provide a spatial scale that can be used to verify bottom up estimates. Aircraft flux measuring systems have previously been used to estimate the anthropogenic top down $\mathrm{CH}_{4}$ emissions from an agricultural area (Wratt et al., 2001); $\mathrm{N}_{2} \mathrm{O}$ emissions from agricultural regions (Desjardins et al., 2010); $\mathrm{CO}_{2}$ and $\mathrm{CH}_{4}$ from a large urban center (Mays et al., 2009); $\mathrm{CH}_{4}$ emissions from an oil and gas production region of Utah (Karion et al., 2013) and $\mathrm{CO}, \mathrm{CH}_{4}$ as well as a variety of halo and hydrocarbons from the northeastern United States (Miller et al., 2012).

In this study, we examine the performance and limits of top down, aircraft based Eddy Covariance (EC), Relaxed Eddy Accumulation (REA) and wavelet covariance techniques to quantify $\mathrm{CH}_{4}$ emissions from an agricultural region. We quantify the magnitude of all the $\mathrm{CH}_{4}$ emissions in an attempt to separate the contribution of the various $\mathrm{CH}_{4}$ sources and better understand the dynamics of these sources. We focus on the $\mathrm{CH}_{4}$ emissions from livestock in an attempt to verify IPCC Tier II bottom up agricultural $\mathrm{CH}_{4}$ emissions inventory estimates using top down estimates based on aircraft based $\mathrm{CH}_{4}$ flux measurements.

\section{Methods}

\subsection{Measurements and study area}

The study area is the combined Districts of Glengarry Prescott Russell, and Stormont Dundas South Glengarry located in eastern Ontario, Canada (area $\approx 7000 \mathrm{~km}^{2}$ ), where agriculture occupies $62 \%$ of the land area (Ontario Ministry of Natural Resources, 2008). The remaining land consists of wetlands, mixed forest, open water and built up areas. Agricultural activities are dominated by dairy farming, with a smaller number of beef cattle, swine, poultry, other animals and cash crops farms. Within the study area, seven $20 \mathrm{~km}$ transects were flown on seven days in the spring of 2011, between April 8 and May 12, generally between 1200 and 1600 EST (Table 1). The EC and wavelet covariance measurements of two days had to be discarded due to pro blems associated with data acquisition system of the fast response $\mathrm{CH}_{4}$ sensor, leaving 5 days with valid flight data for comparing flux results. For each flight, one or two transects approximately perpendicular to the mean wind direction were flown using the National Research Council Canada, Twin Otter atmospheric research aircraft (Desjardins et al., 1982, 2000). Each transect was flown either three or four times at an altitude ranging from 170 to $270 \mathrm{~m}$ above ground level (agl) and each pass along a given transect is a run. About 50 runs were analyzed.

\subsection{Flux measurements using the EC technique}

High frequency aircraft flux measurements of $\mathrm{CH}_{4}$ and $\mathrm{H}_{2} \mathrm{O}$ were obtained using a fast response $(10 \mathrm{~Hz})$ closed path cavity ring down spectrometer analyzer (CRDS; G2301 $\mathrm{f} \mathrm{CO}_{2} / \mathrm{CH}_{4} / \mathrm{H}_{2} \mathrm{O}$ Picarro, Santa

Table 1

Overview of the aircraft measurements, $U=$ wind speed, $\operatorname{dir}=$ wind direction, $T=$ air temperature, $T_{s}=$ surface temperature, $u_{*}=$ friction velocity, $\sigma_{w}=$ standard deviation of the vertical wind, $z_{i}=$ boundary layer height, $R=$ Incident solar radiation. Values represent the average of 3 or 4 runs per transect.

\begin{tabular}{|c|c|c|c|c|c|c|c|c|c|c|c|}
\hline Flt.\# & $\mathrm{mm} / \mathrm{dd}$ & End (EST) & Transect $^{\mathrm{a}}$ & $U\left(\mathrm{~ms} \mathrm{~s}^{1}\right)$ & $\operatorname{dir}\left({ }^{\circ}\right)$ & $T\left({ }^{\circ} \mathrm{C}\right)$ & $T_{s}\left({ }^{\circ} \mathrm{C}\right)$ & $u_{*}\left(\mathrm{~m} \mathrm{~s}^{1}\right)$ & $\sigma_{w}\left(\mathrm{~ms} \mathrm{~s}^{1}\right)$ & $z_{i}(m)$ & $R\left(\mathrm{Wm}^{2}\right)$ \\
\hline \multirow[t]{2}{*}{1} & \multirow[t]{2}{*}{$04 / 08$} & \multirow[t]{2}{*}{$1438-1545$} & $\mathrm{E}_{189}$ & 1.8 & 223 & 8.9 & 16.3 & 0.6 & 1.3 & \multirow[t]{2}{*}{1600} & 595 \\
\hline & & & $\mathrm{F}_{189}$ & 2.8 & 243 & 9.1 & 15.2 & 0.7 & 1.4 & & 561 \\
\hline 2 & $04 / 15$ & $1515-1631$ & $\mathrm{~F}_{176}$ & 2.6 & 64 & 2.0 & 9.0 & 0.5 & 1.5 & 1300 & 587 \\
\hline 3 & $04 / 19$ & $1142-1242$ & $\mathrm{G} 2_{169}$ & 3.0 & 345 & 2.7 & 11.2 & 0.7 & 1.4 & 1300 & 881 \\
\hline 4 & $04 / 27$ & $1356-1459$ & $\mathrm{D}_{161}$ & 6.9 & 95 & 21.4 & 25.5 & 0.5 & 0.9 & 1700 & 707 \\
\hline \multirow[t]{2}{*}{5} & \multirow[t]{2}{*}{$04 / 30$} & \multirow[t]{2}{*}{ 1339-1435 } & $\mathrm{A}_{163}$ & 2.8 & 313 & 13.9 & 25.8 & 0.5 & 1.2 & \multirow[t]{2}{*}{1200} & 933 \\
\hline & & & $\mathrm{C}_{163}$ & 1.7 & 345 & 14.6 & 24.5 & 0.6 & 1.2 & & 894 \\
\hline \multirow[t]{3}{*}{8} & \multirow[t]{3}{*}{$05 / 10$} & \multirow[t]{3}{*}{$1243-1347$} & $\mathrm{I}_{159}$ & 5.9 & 57 & 14.1 & $-\mathrm{b}$ & 0.6 & 1.4 & \multirow[t]{3}{*}{1300} & 989 \\
\hline & & & $\begin{array}{l}159 \\
I_{201}\end{array}$ & 5.8 & 55 & 13.8 & $-{ }^{\mathrm{b}}$ & 0.9 & 1.4 & & 987 \\
\hline & & & $\mathrm{I}_{259}$ & 6.0 & 58 & 13.2 & $-{ }^{\mathrm{b}}$ & 0.7 & 1.5 & & 993 \\
\hline \multirow[t]{3}{*}{10} & \multirow[t]{3}{*}{$05 / 12$} & \multirow[t]{3}{*}{$1259-1409$} & $\mathrm{~F}_{148}$ & 8.6 & 84 & 16.7 & 25.9 & 0.8 & 1.4 & \multirow[t]{3}{*}{900} & 949 \\
\hline & & & $\mathrm{F}_{204}$ & 8.7 & 82 & 16.2 & 25.6 & 0.7 & 1.4 & & 966 \\
\hline & & & $\mathrm{F}_{273}$ & 8.0 & 87 & 15.6 & 25.4 & 0.7 & 1.6 & & 967 \\
\hline
\end{tabular}

\footnotetext{
${ }^{\text {a }}$ Subscript following Transect gives average flight altitude in $\mathrm{m}$ agl.

${ }^{\mathrm{b}}$ Radiative surface temperature instrument failure.
} 
Clara, California, USA), mounted in the aircraft. Ambient air was drawn from a backward facing inlet tube about $20 \mathrm{~cm}$ above the fuselage of the aircraft through a $3.18 \mathrm{~mm}$ I.D. PTFE tube at a rate of $6.5 \mathrm{~L} \mathrm{~min}^{-1}$. The inlet tube length was $3 \mathrm{~m}$, and at the instrument air intake, a $\mathrm{T}$ junction sampled air at a rate of $1 \mathrm{~L} \mathrm{~min}^{-1}$, yielding a sample cell refresh rate of $\sim 3 \mathrm{~s}^{-1}$. Despite being less than typically desired, the sample refresh rate was found to be adequate at the flight altitude of $150300 \mathrm{~m}$, as the maximum flux contribution was found at wavelengths ranging from 1000 to $1500 \mathrm{~m}$, equivalent to approximately $1725 \mathrm{~s}$ of flight time. During the flights, the instrument was operated in $\mathrm{CH}_{4} / \mathrm{H}_{2} \mathrm{O}$ mode which provided a precision for $\mathrm{CH}_{4}$ at $10 \mathrm{~Hz}$ quoted as $<3 \mathrm{ppbv}$. The sensi tivity of the analyzer was found to be constant throughout the experi ment. The observed standard deviation was $1.7 \mathrm{ppbv}$ using a source of air with constant $\mathrm{CH}_{4}$ concentration flowing through the sample cell of the instrument in flight for a period of approximately $400 \mathrm{~s}$. Both wet and dry $\mathrm{CH}_{4}$ concentrations were recorded. The dry concentration values were obtained through the water vapor correction algorithm (Chen et al., 2010) integrated in the fast response CRDS.

Wind velocity relative to the aircraft was measured at a frequency with a nose mounted Rosemount (Shakopee, Minnesota, USA) 858AJ28 5 hole gust boom. Accuracy of the Rosemount gust boom was estimated at $1 \%$, whereas the precision was estimated at $0.5,0.2$ and $0.15 \mathrm{~ms}^{-1}$ for the $u, v$, and $w$ axis, respectively (Desjardins and MacPherson, 1991).

The flux of $\mathrm{CH}_{4}$ by eddy covariance (EC) was calculated as:

$\mathrm{FCH}_{4 E C}=\rho_{d} \overline{w^{\prime} \mathrm{CH}_{4 m}}$

Where $\rho_{\mathrm{d}}\left(\mathrm{kg} \mathrm{m}^{-3}\right)$ is the density of dry air, $\mathrm{w}\left(\mathrm{m} \mathrm{s}^{-1}\right)$ is the vertical wind speed, $\mathrm{CH}_{4 \mathrm{~m}}$ is the mixing ratio of $\mathrm{CH}_{4}$ in $\mu \mathrm{g} \mathrm{kg}^{-1}$ with respect to dry air, prime notations indicate deviations from the mean and the overbar indicates a time average. The time average was approximately $370 \mathrm{~s}$, determined as the time to fly $20 \mathrm{~km}$ at an average ground speed of $55 \mathrm{~m} \mathrm{~s}^{-1}$. The time average is also a spatial average.

The flux of water vapor $\left(\mathrm{FH}_{2} \mathrm{O}_{E C}\right)$ was calculated in a similar manner as:

$\mathrm{FH}_{2} \mathrm{O}_{E C}=\rho_{d} L_{v} \overline{w^{\prime} \mathrm{H}_{2} \mathrm{O}_{m}}$

Where $L_{v}$ is the latent heat of vaporization (mean $=2475 \mathrm{~kJ} \mathrm{~kg}^{-1}$ ), and $\mathrm{H}_{2} \mathrm{O}_{m}$ is mixing ratio of water vapor with respect to dry air $\left(\mathrm{g} \mathrm{kg}^{-1}\right)$.

Prior to calculating the flux density, de spiking of the data was carried out to remove outliers (Vickers and Mahrt, 1997), followed by data synchronization by lagging data to maximize the circular cross correlation between $w$ and the scalar. Weaker and less well defined maxima in correlation with vertical wind speed were found for $\mathrm{CH}_{4}$ as compared to $\mathrm{H}_{2} \mathrm{O}$. Therefore, data synchronization for $\mathrm{CH}_{4}$ was as sumed identical to that observed for $\mathrm{H}_{2} \mathrm{O}$.

\subsection{Flux measurements using the REA technique}

A form of the eddy accumulation (EA) technique developed by Desjardins (1972) and relaxed (REA) by Businger and Oncley (1990) was used to measure the flux of $\mathrm{CH}_{4}$ and $\mathrm{H}_{2} \mathrm{O}$. The sampling system described in Pattey et al. (2007) and Desjardins et al. (2010) for mea suring $\mathrm{N}_{2} \mathrm{O}$ emissions was used to draw the sample from above the cabin of the aircraft. Two fast response 3 way valves directed the air flow either to aluminized bags or to a vent. Three sampling modes of the 3 way valves are defined depending on $w$ measured by the aircraft. The $w$ signal controlling the switching of the valves was high pass fil tered with a third order algorithm with a breakpoint set at $0.002 \mathrm{~Hz}$, which corresponded to a wavelength of approximately $5 \mathrm{~km}$ at the usual flight speed of about $55 \mathrm{~m} \mathrm{~s}^{-1}$. This was done in real time to remove any potential bias in the mean vertical wind speed. The $w$ signal was also time adjusted to correct for any time delay in the sampling assembly. The conditional sampling was as follows:

1. $\mathrm{w}>\mathrm{w}_{\mathrm{o}}$ : Up valve opens to the Up aluminized bag and Down valve opens to vent,
2. $w<-w_{0}$ : Down valve opens to the Down aluminized bag and the Up valve opens to vent,

$-\mathrm{w}_{\mathrm{o}}<\mathrm{w}<\mathrm{w}_{\mathrm{o}}$ : Both valves open to vent and no air samples are collected.

Where $\mathrm{w}_{\mathrm{o}}$ is the 'dead band' threshold, in this case $\mathrm{w}_{\mathrm{o}}=0.10 \mathrm{~m} \mathrm{~s}^{-1}$. The use of the dead band helps to increase the life time of the valves without affecting the flux values significantly (Pattey et al., 1993).

The flux $\mathrm{FCH}_{4 R E A}$ or $\mathrm{FH}_{2} \mathrm{O}_{\mathrm{REA}}$ measured using the REA technique are equal to the product of the difference in $\mathrm{CH}_{4}$ or $\mathrm{H}_{2} \mathrm{O}$ concentration between the two sample bags, the standard deviation of the vertical wind $\sigma_{w}\left(\mathrm{~m} \mathrm{~s}^{-1}\right)$, air density and an empirical coefficient $A$ :

$\mathrm{FCH}_{4 R E A}=A \sigma_{w} \rho_{d}\left(\overline{C^{+}}-\overline{C^{-}}\right) \frac{M\left(\mathrm{CH}_{4}\right)}{M(\text { Air })}$

Where $\left(\overline{C^{+}}\right.$and $\overline{C^{-}}$) are the mean concentration (ppbv) of $\mathrm{CH}_{4}$ of the upward and downward moving air, respectively and $M\left(\mathrm{CH}_{4}\right)$ and $M($ Air $)$ are the molar masses of $\mathrm{CH}_{4}$ and air, respectively. The coeffi cient $A$ is dependent on the magnitude of the dead band and was de termined by simultaneous in situ measurements by EC of water vapor (MacPherson and Desjardins, 1991; Pattey et al., 1993). Total air vo lume accumulated along a $20 \mathrm{~km}$ transect was approximately $60 \mathrm{~L}$, roughly evenly divided between the Up and Down bag. One pair of bags was collected for each run, yielding a $\left(\overline{C^{+}}-\overline{C^{-}}\right)$sample size $n=34$ per transect, per flight. Immediately following the completion of a flight, air samples were brought to the lab and analyzed using a slow response $(0.2 \mathrm{~Hz})$ CRDS analyzer $\left(\mathrm{G} 1301 \mathrm{CO}_{2} / \mathrm{CH}_{4} / \mathrm{H}_{2} \mathrm{O}\right.$, Picarro, Santa Clara, California, USA). A sampling manifold permitted to analyze four pairs of bags consecutively. Although the slow response CRDS is very stable (Allan Variance was minimized for $\mathrm{CH}_{4}$ at $\approx 1300 \mathrm{~s}$ ), to avoid potential bias in the concentration difference due to drift in the mea sured concentration, the sampling manifold switches back and forth between the Up and Down bag every $13 \mathrm{~min}$, with a $3 \mathrm{~min}$ rejection period following a switch between sample bags. Average difference in concentration between the Up and Down bags was then calculated from 9 paired Up and Down samples per bag.

\subsection{Flux measurements using wavelet covariance}

Wavelet analysis (Torrence and Compo, 1998), which is a powerful tool for signal analysis in the frequency and time domain, has been increasingly used to estimate turbulent fluxes obtained using aircraft based sensors (Attié and Durand, 2003; Mahrt and Howell, 1994; Mauder et al., 2007; Metzger et al., 2013). A continuous wavelet transform data analysis routine (Metzger et al., 2013), scripted in the $R$ language (R Development Core Team, 2005) was modified to estimate the wavelet covariance. Following Mauder et al. (2007) and Metzger et al. (2013), the Morlet mother wavelet was selected to conduct the wavelet analysis, written as:

$\psi(n)=\pi^{-1 / 4} e^{i w_{0} n} e^{-n^{2} / 2}$

The Morlet wavelet can be thought of as the product of a repeating wave $\left(e^{i w_{0} n}\right)$ with a Gaussian distribution $\left(e^{-n^{2} / 2}\right)$, which yields a rapidly degrading wave with $w_{o}$, a non dimensional frequency parameter for the mother wavelet, chosen to be 6 . Child wavelets, which are scaled by a dilation parameter $a$ and a time parameter $b$, of the mother wavelet are defined as:

$\psi_{p, a, b}=1 / a^{p} \psi\left(\frac{n-b}{a}\right)$

Where $p$, a normalization parameter, is set as $1 / 2$.

By convolution of the wavelet function with a discrete time se quence $x(n)$ with total length of $N$,

$W_{x}(a, b)=\sum_{n=0}^{N-1} x(n) \psi_{p, a, b}^{*}(n)$ 
Where $\psi_{p, a, b}^{*}$ is the complex conjugate of the wavelet function and $W_{x}$ is the complex wavelet coefficient. By repeating this process along $x(n)$, for every time step $\delta t(1 / 32 \mathrm{~s})$, and for every valid frequency scale, determined by the factor $\delta j(1 / 8)$, a matrix is obtained of complex wavelet coefficients with total length of $N-1$ in the time domain, and length of $J$ in the spatial domain, where

$J=\delta j\left[\log _{2}\left(\frac{(N \delta t)}{2 \delta t}\right)\right]$

In practice, the time series $x(n)$ is zero padded for efficiency, so that $\mathrm{J}$ can be rounded upwards to the next highest power of 2. In our case $\mathrm{J}$ ranged from 97 to 100 , depending on the flight transect. By taking the square of the complex wavelet coefficients, $|W(a, b)|^{2}$, a wavelet sca logram is obtained. The introduction of zero padding adds discontinuity and uncertainty to the analysis, particularly at longer wavelengths. Torrence and Compo (1998) define a Cone of Influence (COI) above which the edge effects become significant as the e folding time for the autocorrelation of wavelet power at each scale. This cut off is chosen such that the introduction of edge discontinuities decreases the wavelet power by $\mathrm{e}^{-2}$. Here, we ignore the $\mathrm{COI}$ and include all wavelengths to cover the greatest range of frequency scales possible, but this means that we have greatest confidence in the wavelet analysis towards the middle of the flight transect, where the $\mathrm{COI}$ is minimized.

The complex conjugate $W_{y}(a, b)^{*}$ of a second time series, $y(n)$ also with length $N$, and synchronized with $x(n)$, yields the cross scalogram between the two signals, $W_{s}(a, b) W_{y}(a, b)^{*}$. The covariance of $x, y$ is then

$\operatorname{cov}_{x, y}=\frac{\delta j \delta t}{C_{\delta} N} \sum_{j=0}^{J} \sum_{n=0}^{N-1} \frac{W_{x}(a, b) W_{y}(a, b)^{*}}{a_{j}}$

Where $C_{\delta}$ is an empirical factor, specific to the Morlet wavelet and is equal to 0.776 (Torrence and Compo, 1998). Here, we present results for both the global wavelet cross scalograms, proportional to the total flux for a transect, as well as localized flux contributions, calculated by averaging covariance for specific ranges of $n$, to estimate the flux a spatial distance of approximately $1 \mathrm{~km}$.

\subsection{Additional aircraft measurements}

The aircraft was equipped to simultaneously measure atmospheric variables such as air temperature (Rosemount 102, Shakopee, Minnesota, USA), radiative surface temperature (Wintronics KT19, Millington, NJ, USA), incident and outgoing short and long wave ra diation (Kipp and Zonen CNR1, Delft, The Netherlands), water vapor and carbon dioxide concentration (LiCor 7000, Lincoln, Nebraska, USA) at $32 \mathrm{~Hz}$ which is equivalent to a spatial resolution of about $1.7 \mathrm{~m}$ at mean ground speed of $55 \mathrm{~m} \mathrm{~s}^{-1}$. All measurements were recorded using a data acquisition system on board the NRC Twin Otter. Table 1 pro vides a summary of some of the basic atmospheric variables measured on board the aircraft.

\subsection{Sources of $\mathrm{CH}_{4}$ in the study area}

When we undertook this study, we thought that the main source of $\mathrm{CH}_{4}$ in the study area was animal husbandry, primarily the dairy sector, and the associated enteric fermentation and manure management emissions. This sector is made up of high yielding (average $8500 \mathrm{~kg}$ milk per head per year) Holstein cattle, which represent $93 \%$ of the total dairy herd, and operates on a supply managed quota system, whereby an individual producer is licensed to sell a certain quota of milk, expressed in $\mathrm{kg}$ of butterfat. In order to produce $1 \mathrm{~kg}$ of butterfat, in the study area, a producer needs to maintain a total herd size of approximately 1.7 head of cattle (R. Versteeg, Dairy Farmers of Ontario, Personal Communication), evenly split between milking cattle and young stock (from birth to calving age). Based on quota information, a georeferenced database of dairy cattle population (total of 70,516 dairy cows and heifers) in the study area was combined with appropriate $\mathrm{CH}_{4}$ emission factors and footprint information to estimate bottom up $\mathrm{CH}_{4}$ emissions for each transect.

Average $\mathrm{CH}_{4}$ emission factors per head were estimated based on measurements made during spring on two farms in the study area (VanderZaag et al., 2014). The average (milking cows and young stock) emission factors were 88 and $66 \mathrm{~kg} \mathrm{CH}_{4}$ per head per year for enteric fermentation $\left(\mathrm{EF}_{\mathrm{EF}}\right)$ and manure management $\left(\mathrm{MM}_{\mathrm{EF}}\right)$, respectively. Although the emission factors are expressed per year, they are based on spring measurements only, so as to reflect the conditions during aircraft measurements. The $\mathrm{EF}_{\mathrm{EF}}$ measured is consistent with the provincial scale emission factor ( $92 \mathrm{~kg} \mathrm{CH}_{4} \mathrm{hd}^{-1} \mathrm{yr}^{-1}$ ) used in Canada's IPCC Tier II approach (Vergé et al., 2007), however the $\mathrm{MM}_{\mathrm{EF}}$ is approximately 2.5 times larger than the equivalent emission factor (27 $\mathrm{kg} \mathrm{CH}_{4} \mathrm{hd}^{-1} \mathrm{yr}^{-1}$ ). The relatively large $\mathrm{MM}_{\mathrm{EF}}$ is due to the fact that manure storage tanks in the study region were likely at capacity, due to the timing of the measurement campaign.

Although dairy farming is the primary agricultural activity, there are also a smaller number of beef cattle, swine, poultry and other farms in the study area. For instance, the 2011 Census of Agriculture reported that there were approximately 16,500 head of beef cattle in the study area, equal to roughly $20 \%$ of the size of the dairy herd (Statistics Canada, 2016). Although we do not have information on the geographic location of these animals within the study area, we attempted to identify these farms and account for their emissions by combining high resolution satellite imagery and the known dairy farm geolocations, and examining the area surrounding the flight transects to identify the presence of other farms. These farms, not present in the dairy database, were classified as dairy, beef, pork, poultry or other, based on the presence and geometry of barns, manure tanks, pastures, silos, and si lage storage. The annual $\mathrm{CH}_{4}$ emissions from these farms was then scaled to be equal to a fraction of the median rate of emissions from a dairy farm in this study ( $\approx 14,000 \mathrm{~kg} \mathrm{CH}_{4} \mathrm{yr}^{-1}$ ) based on the annual per head rates of emissions (Environment Canada, 2015a), and on re lative farm sizes in the study region (Statistics Canada, 2016) as fol lows: dairy, 0.5; beef, 0.375 ; swine, 0.25 ; poultry, 0.125 ; grain, 0 ; other, 0.05. The $\mathrm{CH}_{4}$ emission scaling factors for these farms are sub jective; however the choice of scaling factor by farm type was guided by the following reasoning:

1. Dairy farms identified by visual survey were observed to be smaller than average size compared with farms in the dairy database and are assumed to produce less $\mathrm{CH}_{4}$ per head;

2. The beef farms in the region have on average $58 \%$ as many head as a dairy farm, and beef cattle typically emit $65 \%$ as much $\mathrm{CH}_{4}$ than dairy cattle due to the type and amount of feed consumed, and tend to store manure as a solid, or leave it unmanaged in the field, which leads to significantly reduced $\mathrm{CH}_{4}$ emissions (Environment Canada, 2015a);

3. Swine do not emit $\mathrm{CH}_{4}$ by enteric fermentation in significant quantities, but their manure, which is typically stored as a liquid, is a source of $\mathrm{CH}_{4}$. Total per head $\mathrm{CH}_{4}$ emissions are approximately $5 \%$ of a dairy cow (Environment Canada, 2015a) and the number of head per swine farm is approximately 5 times greater than a dairy farm;

4. Poultry farms emit a minimal amount of $\mathrm{CH}_{4}$ considering that there is no enteric fermentation and their manure is typically stored as a solid, however the number of head per farm is generally very large; 5 . Other farms (e.g. horse, deer) are generally very small in size.

During the analysis of the data, we found out that wetlands, which covered approximately $14 \%$ of the region (Ontario Ministry of Natural Resources, 2008), were an important source $\mathrm{CH}_{4}$ in the study area. Little was known about the magnitude of the $\mathrm{CH}_{4}$ emissions from the wetlands in the study area however a multi year study in the Mer Bleue bog $\left(28 \mathrm{~km}^{2}\right)$ located north of the study area had reported spring time 
wetland $\mathrm{CH}_{4}$ emissions of $1030 \mathrm{mg} \mathrm{CH} \mathrm{m}^{-2} \mathrm{~d}^{-1}$ (Moore et al., 2011). For wetlands to the east of the study area, daily springtime emissions typically ranged from 0 to $25 \mathrm{mg} \mathrm{CH}_{4} \mathrm{~m}^{-2} \mathrm{~d}^{-1}$ depending on the water table depth and temperature (Moore and Knowles, 1990), with max imum daily springtime emissions exceeding $200 \mathrm{mg} \mathrm{CH}_{4} \mathrm{~m}^{-2} \mathrm{~d}^{-1}$.

\subsection{Footprint analysis}

To compare the bottom up inventory based $\mathrm{CH}_{4}$ emission estimates with the top down aircraft flux measurements, footprint modelling is required. The backward Lagrangian Stochastic model LPDM B of Kljun et al. (2002), which is valid for a wide range of measurement heights and atmospheric conditions, is therefore reasonably well suited for the application to aircraft flux measurements. We employed a para meterization of LPDM B, presented in Kljun et al. (2004) and im plemented in R software (R Development Core Team, 2005) to derive a $100 \mathrm{~m}$ spatial resolution map of the flux footprint for each flight transect (Metzger et al., 2013). The input parameters required for this model are the sampling height $z$, roughness length $z_{0}$, friction velocity $u^{*}$, the convective velocity scale $w^{*}$, the height of the planetary boundary layer $z_{i}$, the Obukhov length $L$, the standard deviations of the vertical wind $\sigma_{w}$, and cross wind component $\sigma_{v}$ (Mauder et al., 2008), and wind speed $u$. All of these parameters were determined directly from aircraft measurements specific to each flight transect, except for $z_{i}$ and $\mathrm{z}_{\mathrm{o}}$. Boundary layer height was determined by aircraft sounding at the beginning of each flight from a vertical temperature profile, and was found to range between 900 and $1600 \mathrm{~m}$ agl. An effective rough ness length, representative of a mixed agricultural landscape prior to crop development, of $z_{o}=0.03 \mathrm{~m}$ was used (Stull, 1988). In order for the footprint model to be valid, it was necessary to assume that the entire flux measured by the aircraft originates from surface sources, meaning that the influence of entrainment is negligible at the flight altitude.

\section{Results}

\subsection{Testing the EC system}

In order to determine the detection limit of $\mathrm{CH}_{4}$ fluxes using the EC technique equipped with the fast response CRDS analyzer (Picarro G2301 f), a run on May 12 was carried out while sampling air from a compressed air cylinder with $\left[\mathrm{CH}_{4}\right] \approx 2.020 \mathrm{ppmv}$, instead of ambient air, expecting $F C H_{4 E C}=0$. However, during this run, a positive flux equal to $7.4 \mathrm{mg} \mathrm{CH}_{4} \mathrm{~m}^{-2} \mathrm{~d}^{-1}$ was found. Post flight analysis indicated that there was a relationship between cavity pressure and the observed $\mathrm{CH}_{4}$ concentration (Fig. 1a). Cross correlation analyses demonstrated maxima and minima in correlations between $\mathrm{CH}_{4}$ and $w$, and $\mathrm{CH}_{4}$ and cavity pressure (Fig. 1b). The observed $\mathrm{CH}_{4}$ concentration was cor rected using the trend line in Fig. 1a to adjust the concentration values for the pressure fluctuations in the cavity. The uncorrected and cor rected cumulative $\mathrm{CH}_{4}$ flux for this null flux flight is shown in Fig. 1c, demonstrating that the correction was effective in reducing the spurious
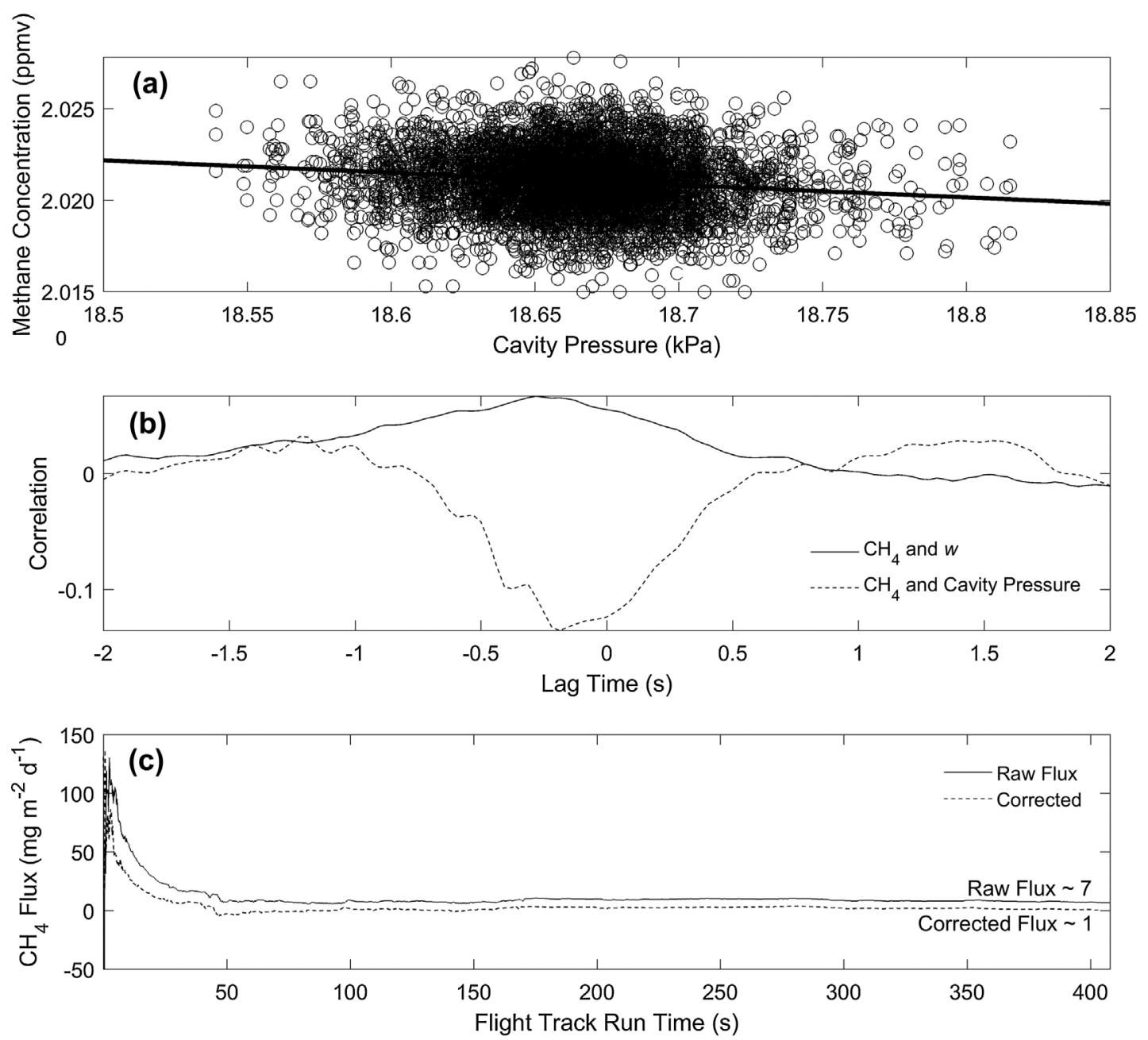

Fig. 1. Spurious inverse relationship between cavity pressure and methane concentration (a), cross correlation between methane and vertical wind speed and cavity pressure (b) and the raw and corrected cumulative methane flux for the null flux run (c). 
flux from $\sim 7$ to $\sim 1 \mathrm{mg} \mathrm{CH}_{4} \mathrm{~m}^{-2} \mathrm{~d}^{-1}$. This pressure correction was applied to all flux measurement runs.

\subsection{Testing the REA system}

Aircraft based flux measurements using the REA technique require a precise determination of the time lag between the detection of the $w$ signal crossing the deadband thresholds $\left( \pm 0.1 \mathrm{~m} \mathrm{~s}^{-1}\right)$ and the actua tion of valves to direct air flow into the appropriate sample bag (Moravek et al., 2013). Prior to the measurement campaign, the overall time lag was determined as $15 / 32 \mathrm{~s}$, representing the combined time for the detection of $\mathrm{w}$ exceeding the dead band and the actuation of the valves and the average displacement time for eddies detected at the nose of the aircraft to being sampled mid plane (5/32 s), as well as the transport time of sampled air in the tubing to the valves and the time for the valve actuation to be $10 / 32 \mathrm{~s}$. We assumed that the time for the detection of $w$ exceeding the dead band and the actuation of the valves to be constant throughout the study. We calculated the range ( $\max \min$ ) in mean aircraft groundspeed could affect the displacement time of eddies by 1.5/32 s and calculated that changes in air pressure and temperature could affect transport time in the REA tubing by 0.5 / $32 \mathrm{~s}$. Accumulating these time lags, the theoretical error in the time lag error caused by variability in groundspeed and atmospheric conditions during the measurement campaign was $\pm 2 / 32 \mathrm{~s}$. However, using the high frequency signals of the EC system, the range in the timing of maximum correlation between $w$ and water vapor was greater, 7/32 s. We considered this value to be a proxy for the potential time lag error in the REA system.

Following Moravek et al. (2013), the flux recovery for different time lags $\left(\operatorname{Rec}_{\text {lag }}\right)$ was estimated using the fast response analyzer and $w$ sig nals on board of the aircraft by simulating the effect of the lag un certainty on the flux determination using the REA technique as follows:

$\operatorname{Rec}_{\text {lag }-\mathrm{H} 2 \mathrm{O}}=\frac{\mathrm{FH}_{2} \mathrm{O}_{\mathrm{REASIM}-\mathrm{l}}}{\mathrm{FH}_{2} \mathrm{O}_{\mathrm{REASIM}}}$

Where $\mathrm{FH}_{2} \mathrm{O}_{\text {REASIM-l }}$ is the lagged flux of water vapor that is estimated using the simulated REA approach and $\mathrm{FH}_{2} \mathrm{O}_{\text {REASIM }}$ is the unlagged flux of water vapor that is estimated using the REA simulated approach. The lagged flux is calculated for the lag range of $\pm 9 / 32 \mathrm{~s}$, in increments of $3 / 32 \mathrm{~s}$. We find that at a lag of $9 / 32 \mathrm{~s}, \operatorname{Rec}_{\text {lag }-\mathrm{H} 2 \mathrm{O}}=0.95 \pm 0.05$, representing a $5 \%$ flux loss. Repeating the same analysis for $\mathrm{CH}_{4}$, a larger fraction of the flux is lost, $\operatorname{Rec}_{\text {lag }-\mathrm{CH} 4}=0.80 \pm 0.47$. These flux losses are smaller than reported by Moravek et al. (2013), who found flux losses ranging from 20 to $50 \%$ depending on the scalar being measured, at lag times of $616 / 32 \mathrm{~s}$.

In order to evaluate the detection limit of the REA technique, la boratory tests, using the slow response CRDS analyzer (Picarro G1301), were conducted to analyze the concentration difference in the sample bags filled with identical ambient air, expecting that $\left(\overline{C^{+}}-\overline{C^{-}}\right) \approx 0$. During these tests, sample bags were analyzed using the same proce dure as for the bags collected using the airborne REA system. The ability to resolve small differences in $\mathrm{CH}_{4}$ concentration was de termined by calculating $\left(\overline{C^{+}}-\overline{C^{-}}\right)$in 13 paired samples of ambient air. Average $\mathrm{SCH}_{4}$ in the 13 pairs was $-0.02 \pm 0.09 \mathrm{ppbv}$. The standard deviation for any three samples (chosen as the average number of runs per transect) was $0.08 \mathrm{ppbv} \mathrm{CH}_{4}$. Based on these tests and given average measurement conditions during measurement flights, we therefore ex pect that the flux detection limit of the REA sample analysis for any one transect is better than $\pm 6 \mathrm{mg} \mathrm{CH} \mathrm{CH}^{-2} \mathrm{~d}^{-1} 95 \%$ of the time.

\subsection{Comparison of $\mathrm{H}_{2} \mathrm{O}$ and $\mathrm{CH}_{4}$ fluxes using EC, REA and wavelet covariance}

The EC, REA and wavelet covariance techniques were used to measure fluxes of water vapor and $\mathrm{CH}_{4}$. Water vapor abundance and its fluctuations about the mean are greater than for $\mathrm{CH}_{4}$, and therefore

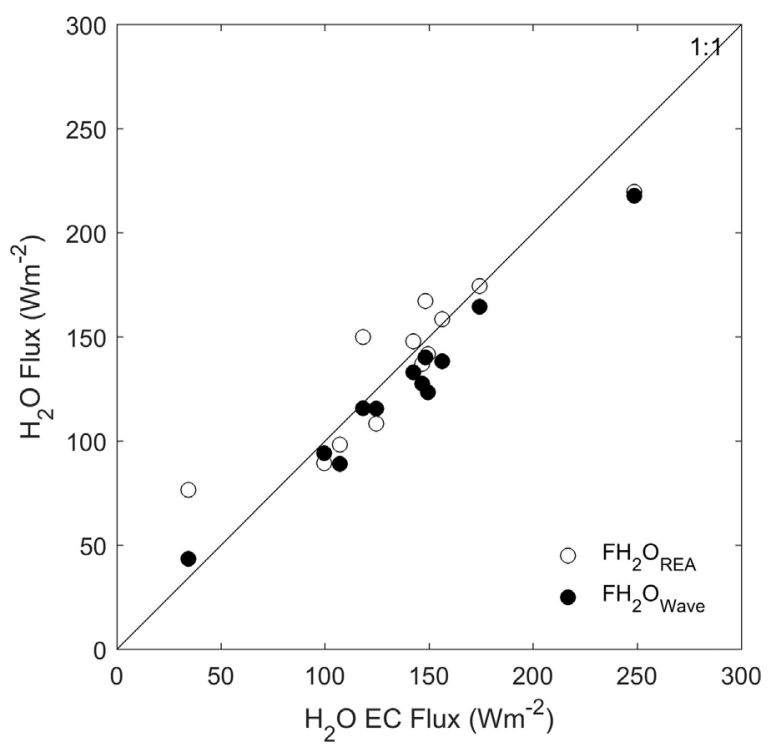

Fig. 2. Comparison of flight transect averaged $\mathrm{H}_{2} \mathrm{O}$ fluxes using EC, wavelet covariance and REA.

represent a simpler initial test of the measurement system. Mean \pm 1 standard error $(\bar{\mu} \pm 1 S E)$ water vapor fluxes were $128 \pm 12,134 \pm 9$ and $118 \pm 9 \mathrm{~W} \mathrm{~m}^{-2}$ for the EC, REA and wavelet covariance techni ques respectively (Fig. 2). Similar comparisons of the $\mathrm{CH}_{4}$ flux were carried out, and as expected the relationship was weaker, with greater scatter in the data. Mean methane fluxes $(\bar{\mu} \pm 1 S E)$ were $17 \pm 4$, $19 \pm 3$ and $16 \pm 3 \mathrm{mg} \mathrm{CH}_{4} \mathrm{~m}^{-2} \mathrm{~d}^{-1}$ for the EC, REA and wavelet covariance techniques respectively and are not statistically different.

Wavelet covariance estimates of $\mathrm{H}_{2} \mathrm{O}$ and $\mathrm{CH}_{4}$ fluxes taken over all frequency scales are well correlated with EC estimates $\left(\mathrm{R}^{2}=0.97\right.$ and 0.85 respectively), but underestimated average EC estimates by 9 and $8 \%$ respectively (Fig. 2, Table 2). This level of underestimation for wavelet covariance is slightly greater than reported by Mauder et al. (2007) for energy and ozone fluxes, but equal to the underestimate reported for $\mathrm{CO}_{2}$. In Mauder et al. (2007), the flight transects were $115 \mathrm{~km}$ long as compared to $20 \mathrm{~km}$ in this study, and for a study fea turing flight transects of comparable length (Metzger et al., 2013), flux underestimation by the wavelet approach was reported as -7 to $-3 \%$ of the median, more comparable to the results of this study. This sug gests that the coefficients chosen and the Morlet mother wavelet were appropriate for this analysis.

\subsection{Comparison of top down and bottom up estimates of $\mathrm{CH}_{4}$ emissions}

Top down measurements of $\mathrm{CH}_{4}$ emissions were compared to bottom up estimates based on geolocated farms, emission factors and a footprint model. From visual analysis using satellite imagery, $91 \%$ of the farms examined were identified as having a dairy barn less than $200 \mathrm{~m}$ from the geolocation. In the worst case, the nearest dairy barn was identified as being $600 \mathrm{~m}$ from the geolocation. The dairy cattle population estimates based on the dairy database were compared to a separate estimate of population by the Census of Agriculture (Statistics Canada, 2016), conducted in May 2011. The total number of farms reporting dairy cows in the study area according to the Census of Agriculture was 676 , which was $8 \%$ higher than the 624 farms in the georeferenced database. Total number of dairy heifers plus cows re ported in the Census of Agriculture was 72,191 head as compared to 70,516 head in the georeferenced database, an underestimate of $3 \%$. It is expected that the Census would produce a slightly larger estimate of farms and dairy cattle population, as some farmers might have a few dairy cows, but might not sell milk. These farms would be identified by the Census, but would not be identified in the georeferenced database. 
Table 2

Number of farms integrated in the aircraft footprint, top-down and bottom-up estimates of $\mathrm{CH}_{4}$ emissions and percent area in the flux footprint for selected land use types.

\begin{tabular}{|c|c|c|c|c|c|c|c|c|}
\hline Flight \# & Transect & $\begin{array}{l}\text { Farms in the } \\
\text { aircraft } \\
\text { footprint } \\
\#\end{array}$ & $\begin{array}{l}\text { Top-down EC estimates of } \\
\mathrm{CH}_{4} \text { emissions } \\
\mathrm{mg} \mathrm{CH}_{4} \mathrm{~m}^{2} \mathrm{~d}^{1}\end{array}$ & $\begin{array}{l}\text { Top-down REA } \\
\text { estimates of } \mathrm{CH}_{4} \\
\text { emissions }\end{array}$ & $\begin{array}{l}\text { Top-down Wavelet } \\
\text { estimates of } \mathrm{CH}_{4} \\
\text { emissions }\end{array}$ & $\begin{array}{l}\text { Bottom-up } \\
\text { estimates of } \mathrm{CH}_{4} \\
\text { emissions }\end{array}$ & $\begin{array}{l}\text { Agriculture in Flux } \\
\text { Footprint } \\
\%\end{array}$ & $\begin{array}{l}\text { Wetlands in Flux } \\
\text { Footprint }\end{array}$ \\
\hline 1 & $E_{189}$ & 114 & 21 & 20 & 15 & 15 & 83 & 8 \\
\hline 1 & $\mathrm{~F}_{189}$ & 45 & 11 & 12 & 8 & 5 & 55 & 29 \\
\hline 2 & $\mathrm{~F}_{176}$ & 68 & 4 & 3 & 3 & 8 & 55 & 25 \\
\hline 3 & $\mathrm{G} 2_{169}$ & 64 & 7 & 9 & 7 & 5 & 57 & 22 \\
\hline 4 & $\mathrm{D}_{161}$ & 61 & $-^{\mathrm{a}}$ & 37 & $-{ }^{\mathrm{a}}$ & 5 & 59 & 22 \\
\hline 5 & $\mathrm{~A}_{163}$ & 44 & $-^{\mathrm{a}}$ & 19 & $-{ }^{\mathrm{a}}$ & 9 & 62 & 9 \\
\hline 5 & $\mathrm{C}_{163}$ & 86 & $-^{\mathrm{a}}$ & 12 & $-{ }^{\mathrm{a}}$ & 20 & 77 & 5 \\
\hline 8 & $\mathrm{I}_{159}$ & 58 & 27 & 20 & 23 & 4 & 57 & 30 \\
\hline 8 & $\mathrm{I}_{201}$ & 90 & 26 & 10 & 21 & 4 & & \\
\hline 8 & $\mathrm{I}_{259}$ & 90 & 31 & 26 & 30 & 4 & & \\
\hline 10 & $\mathrm{~F}_{204}$ & 74 & 10 & 29 & 7 & 8 & 50 & 29 \\
\hline 10 & $\mathrm{~F}_{273}$ & 78 & 13 & 24 & 19 & 8 & & \\
\hline 10 & $\mathrm{~F}_{148}$ & 73 & 27 & 23 & 28 & 6 & & \\
\hline
\end{tabular}

${ }^{\text {a }}$ Failure of fast-response CRDS analyzer.

Based on this information, we believe the georeferenced database of dairy cattle to be an accurate representation of the population and lo cation of dairy cattle in the study area.

Methane emissions in the study area from enteric fermentation and manure management (Fig. 3) were estimated to be $13.4 \times 10^{6} \mathrm{~kg} \mathrm{CH}_{4} \mathrm{yr}^{-1}$ approximately $5 \mathrm{mg} \mathrm{m}^{-2} \mathrm{~d}^{-1}$ using bottom up estimates. Approximately $71 \%$ of $\mathrm{CH}_{4}$ emissions were estimated to originate from dairy farms, beef farms accounting for $17 \%$, and all other farms accounting for the remaining $12 \%$.

The downwind footprint distance to include $80 \%$ of the flux con tribution was on average $3.7 \pm 0.8 \mathrm{~km}$, which incorporates the emissions from $75 \pm 18$ farms. Despite the large number of farms in cluded in the average bottom up footprint, a smaller number of farms contributed a great proportion. For instance, transect $1 \mathrm{E}$ featured the largest number of farms in the footprint of any flight transect, yet $50 \%$ of the total bottom up flux was estimated to have originated from only 12 farms (Fig. 4). On average, 50\% of the total footprint adjusted bottom up methane emissions were estimated to originate from 8 farms. These were not necessarily large farms, but were those that fell within the area of the greatest relative $\mathrm{CH}_{4}$ contribution, according to the footprint calculations. It was expected that the flux measurements would provide higher $\mathrm{CH}_{4}$ emissions as compared to the inventory

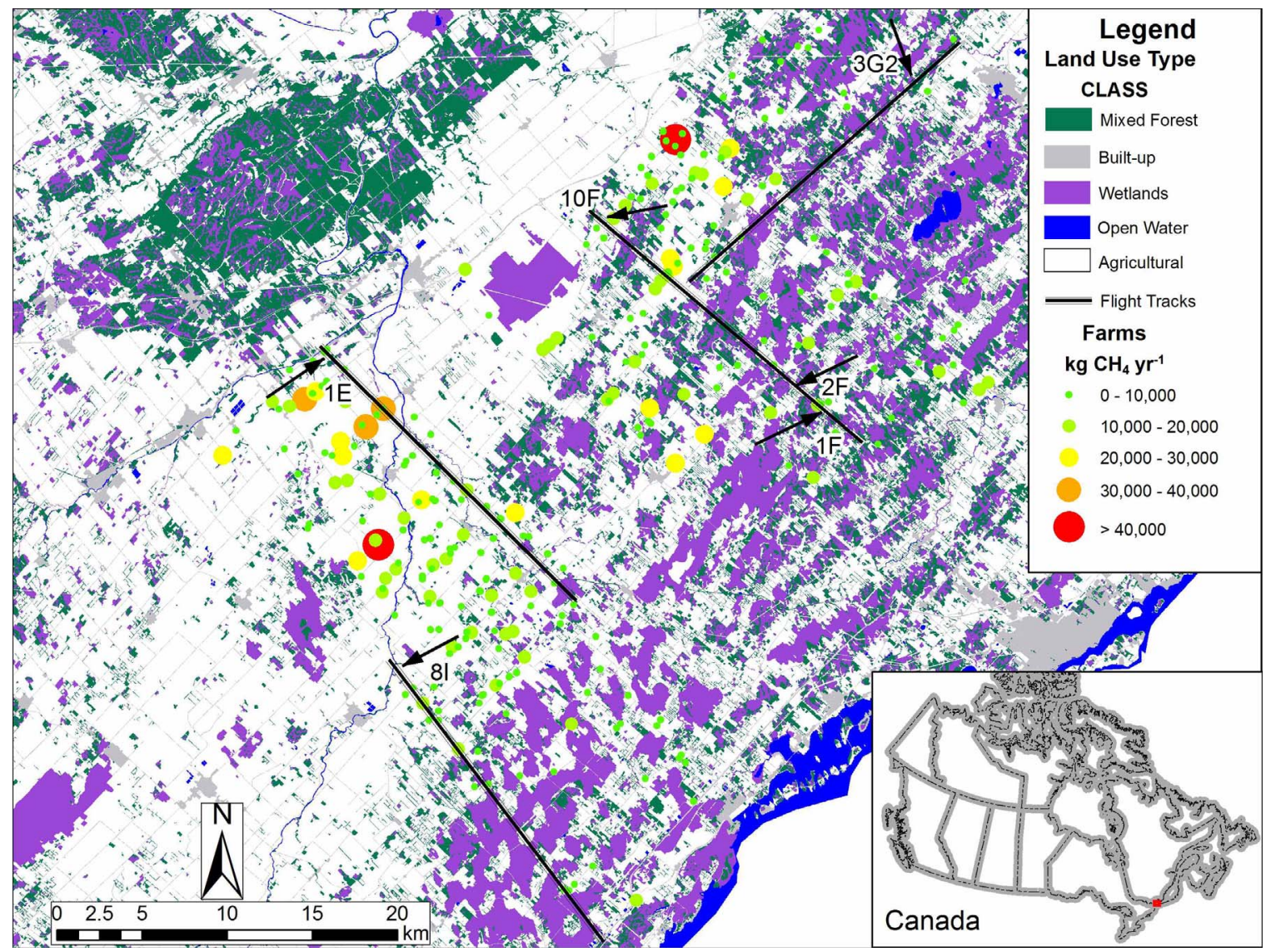

Fig. 3. Overview of the study area showing estimated farm-scale $\mathrm{CH}_{4}$ sources, flight transects and land-use type. Arrows show the mean wind direction for the corresponding flight transects. 


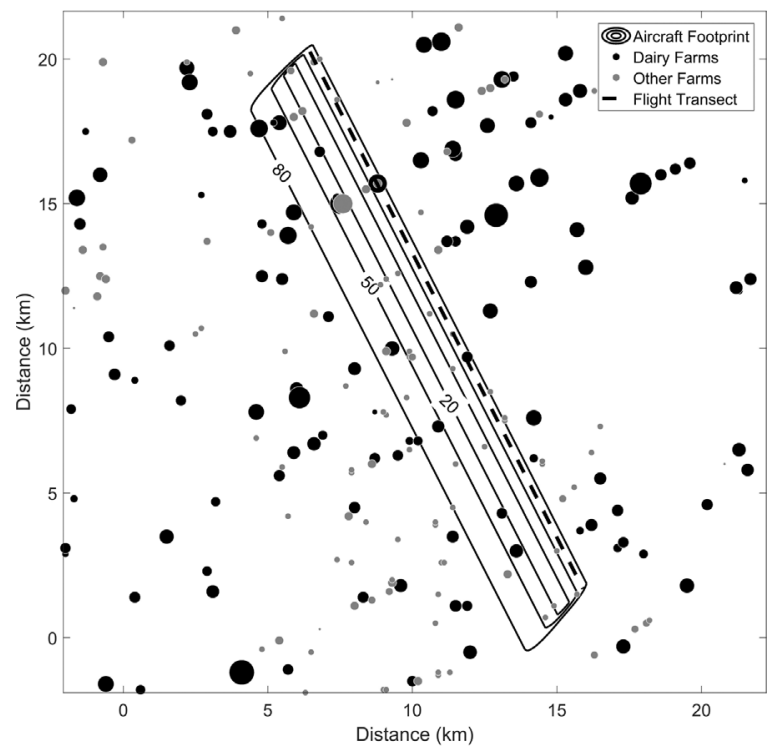

Fig. 4. Flight 1, transect $\mathrm{E}$, showing the distribution of farm-based dairy and other $\mathrm{CH}_{4}$ sources. Isolines show the source-area flux footprint contribution (\%). Marker size is proportional to estimated farm-based $\mathrm{CH}_{4}$ emissions.

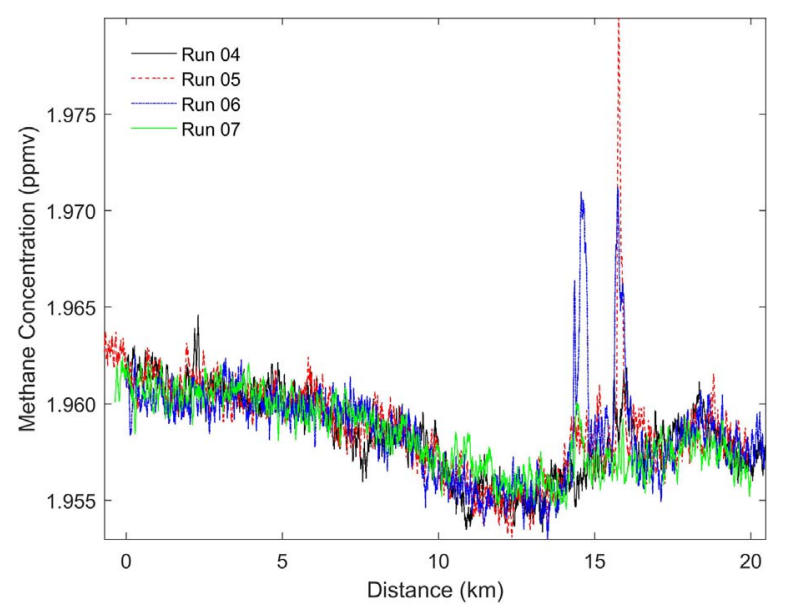

Fig. 5. One second average $\mathrm{CH}_{4}$ concentration during four runs along flight 1 , transect $\mathrm{E}$.

based approach, as the top down estimates incorporated emissions from all sources, whereas the inventory based approach only included $\mathrm{CH}_{4}$ emissions from animal husbandry. In most of the transects, top down $\mathrm{CH}_{4}$ flux measurements were substantially larger than the inventory based bottom up emission estimates (average top down estimate was $250 \%$ of the bottom up estimate, Table 2). Superimposing the flight transects on a land use map, we soon realized that wetlands were contributing to the larger than expected $\mathrm{CH}_{4}$ emissions. Estimating the fractional coverage of different land use types in the aircraft footprint demonstrated a variable source area contribution associated with wet lands (Fig. 3, Table 2), ranging from 8 (transect 1E) to 30\% (transect 8I) coverage. Flight 1 transect $\mathrm{E}$, which had one of the smallest percentage of wetland in the flux footprint, should be the best data set to compare top down and bottom up agricultural $\mathrm{CH}_{4}$ emissions. Top down $\mathrm{CH}_{4}$ emissions for that transect were found to be approximately $30 \%$ greater than for the bottom up estimates. However, for that transect, a large source of $\mathrm{CH}_{4}$ was detected during each run (Fig. 5). Since the increase in $\mathrm{CH}_{4}$ concentration was short, lasting $615 \mathrm{~s}$, and not necessarily al ways correlated with vertical wind, the impact on $\mathrm{FCH}_{4 E C}$ was not al ways detected. The source of the large increase in $\mathrm{CH}_{4}$ concentration were, through visual inspection of satellite imagery, traced to a muni cipal wastewater treatment system, and a farm based biodigester lo cated 500 and 1300 m, respectively upwind of the transect. Knowing that local sources during one run of transect $\mathrm{E}$ contaminated the top down emission estimate, when we removed this run and re compute the average $\mathrm{FCH}_{4 E C}$, we found a $\mathrm{CH}_{4}$ flux value of $12 \mathrm{mg} \mathrm{m}^{-2} \mathrm{~d}^{-1}$, ap proximately equal to the bottom up estimate.

\subsection{Confounding sources of $\mathrm{CH}_{4}$}

The wetlands that fell within the aircraft footprint were the main confounding source of $\mathrm{CH}_{4}$. In the study area as a whole, $62 \%$ of the land use is classified as agricultural, $14 \%$ is classified as wetlands and $12 \%$ as forest (Ontario Ministry of Natural Resources, 2008). Con sidering the footprint of each transect separately, we find that the agricultural area varies from a high of $83 \%$, to a low of $50 \%$, whereas the wetland area varies approximately inversely to the agricultural land area from a high of $30 \%$ to a low of $8 \%$ (Table 2). We expect that both agriculture and wetlands are significant sources of $\mathrm{CH}_{4}$ while the forest is likely a small sink of $\mathrm{CH}_{4}$ (Lessard et al., 1994). If we scale the bottom up $\mathrm{CH}_{4}$ emissions to include the flux from the proportional area of wetlands, with typical emissions ranging from 10 to $30 \mathrm{mg} \mathrm{CH}_{4} \mathrm{~m}^{-2} \mathrm{~d}^{-1}$ (Moore et al., 2011; Moore and Knowles, 1990), the average bottom up flux in the aircraft footprint is increased from 7 to $1014 \mathrm{mg} \mathrm{CH}_{4} \mathrm{~m}^{-2} \mathrm{~d}^{-1}$. Considering extreme rates of $\mathrm{CH}_{4}$ emissions observed from wetlands north of the study area, $\approx 100200 \mathrm{mg} \mathrm{CH}_{4} \mathrm{~m}^{-2} \mathrm{~d}^{-1}$ (Moore and Knowles, 1990), average bottom up emissions in the aircraft footprint could range from 28 to $48 \mathrm{mg} \mathrm{m}^{-2} \mathrm{~d}^{-1}$, which significantly exceed the total top down mea sured $\mathrm{CH}_{4}$ emissions.

Transect $\mathrm{F}$ was flown on three days with surface temperature $\left(\mathrm{T}_{\mathrm{s}}\right)$ which varied from 9 to $25{ }^{\circ} \mathrm{C}$ (Table 1 ). We observed an increase in $\mathrm{CH}_{4}$ emissions from $\sim 0$ to $\sim 24 \mathrm{mg} \mathrm{m}^{-2} \mathrm{~d}^{-1}$ along that transect (Table 2). On April 8th, $\mathrm{T}_{\mathrm{s}}$ had an intermediate temperature of $\sim 15^{\circ} \mathrm{C}$ and the methane flux was $\sim 10 \mathrm{mg} \mathrm{m}^{-2} \mathrm{~d}^{-1}$. This transect featured a northern end that was predominantly ( $>60 \%$ ) agricultural, and a southern end that had roughly an equal mixture of agriculture, wetlands and forest. Though the source area footprint was slightly different on each day, the average land use coverage for agriculture and wetlands in the footprints agreed to within $\pm 5 \%$. Temperature impacts $\mathrm{CH}_{4}$ emissions from wetlands considerably by influencing the metabolic rate of methano gens. Turetsky et al. (2014) provided a temperature relationship to estimate $\mathrm{CH}_{4}$ emissions from temperate wetlands which agrees rea sonably well with the change in $\mathrm{CH}_{4}$ emissions that we observed. The top down $\mathrm{CH}_{4}$ flux along transect $\mathrm{F}$ on these three days indicate that change in surface temperatures lead to different $\mathrm{CH}_{4}$ flux because of the presence of wetlands. Since this suggests that $\mathrm{CH}_{4}$ emissions from wetlands are the predominant source of unaccounted $\mathrm{CH}_{4}$ emissions, a spatially resolved flux analysis should show $\mathrm{CH}_{4}$ emissions increasing with increasing fractional wetland contribution in the flux footprint, with a high surface temperature. Fig. 6 shows the relative contribution of land use types to the footprint for flight 2 transect $\mathrm{F}$, and the $1 \mathrm{~km}$ average spatially resolved $\mathrm{CH}_{4}$ flux. This shows a slight uptake of $\mathrm{CH}_{4}$ for the southern portion of transect $\mathrm{F}$ and emissions of $815 \mathrm{mg} \mathrm{CH}_{4} \mathrm{~m}^{-2} \mathrm{~d}^{-1}$ at the northern end. The data in Fig. 7, which was measured under much warmer conditions, shows a similar analysis for flight 10 transect $\mathrm{F}$, where moving from south to north, average $\mathrm{CH}_{4}$ fluxes increase from 0 to over $40 \mathrm{mg} \mathrm{CH}_{4} \mathrm{~m}^{-2} \mathrm{~d}^{-1}$, as the fractional area of wetlands in the footprint increases from 15 to $40 \%$. At the northern end, land use was predominantly agricultural and $\mathrm{CH}_{4}$ flux decreases to about $10 \mathrm{mg} \mathrm{CH}_{4} \mathrm{~m}^{-2} \mathrm{~d}^{-1}$. The data in Figs. 6 and 7 clearly demonstrate the challenges of reconciling agricultural $\mathrm{CH}_{4}$ in ventories with top down measurements.

In the case of flight 1 transect $\mathrm{E}$, agricultural land use predominates in the flux footprint (Fig. 8) and as expected the spatially resolved flux are primarily a result of the agricultural $\mathrm{CH}_{4}$ sources within the flux 

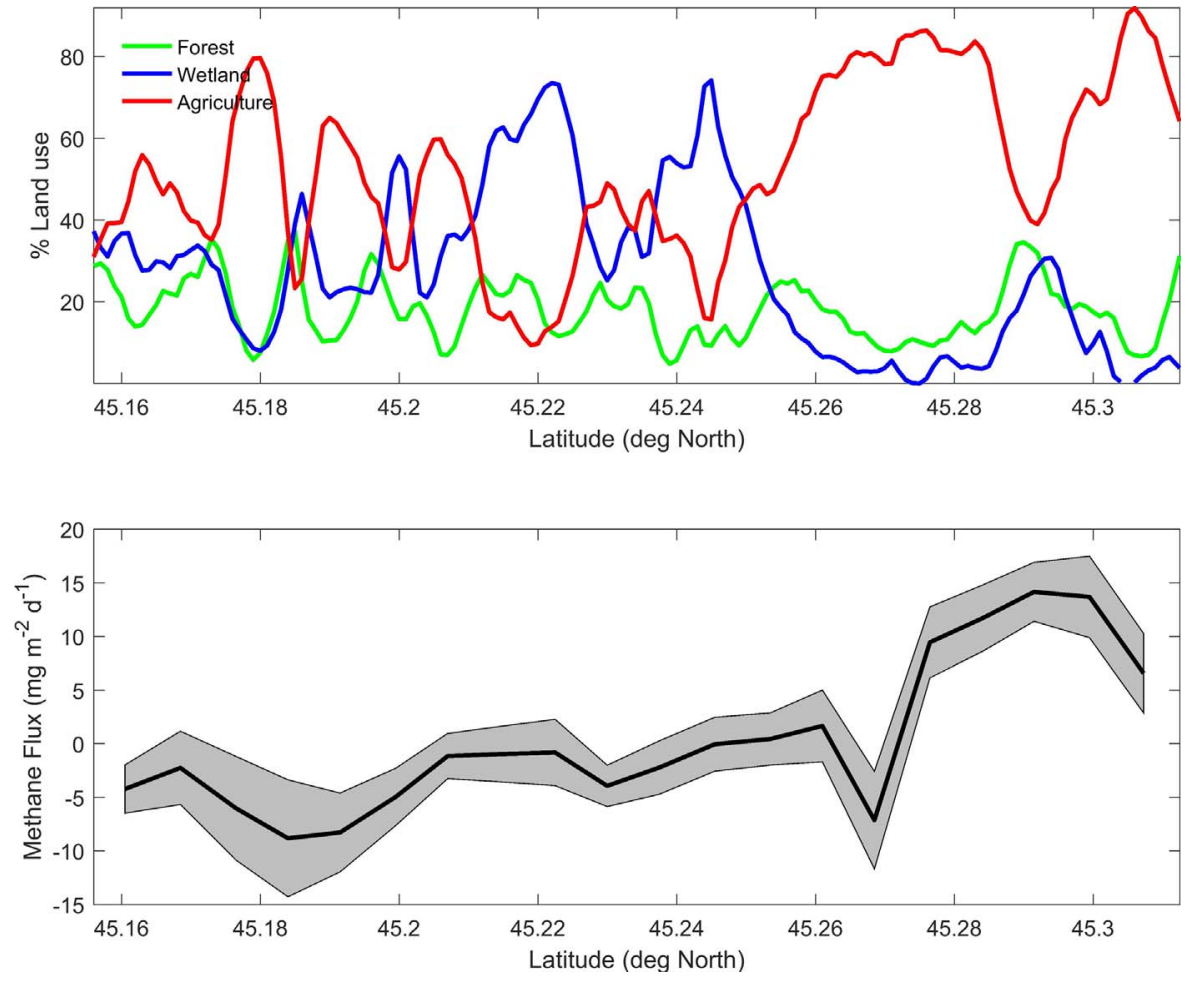

Fig. 6. Land use contributions to the flux footprint for flight 2 , transect $\mathrm{F}$ (upper panel) and $1 \mathrm{~km}$ spatially resolved $\mathrm{CH}_{4}$ flux (lower panel). Shaded grey area represents $\pm 1 \mathrm{SE}$, based on $\mathrm{n}=4$ repeated runs. Average surface temperature was $9.0^{\circ} \mathrm{C}$. footprint. However, because of the mixing that takes place in the at mosphere, the top down measurements are less variable than the footprint adjusted bottom up estimates, which are associated with a limited number of barns. These results demonstrate that it is difficult to duplicate in the footprint adjusted bottom up estimates of $\mathrm{CH}_{4}$ emis sions the actual mixing that takes place in the boundary layer.

\section{Discussion}

\subsection{Regional estimates of $\mathrm{H}_{2} \mathrm{O}$ and $\mathrm{CH}_{4}$ fluxes}

Aircraft based flux measurements of $\mathrm{H}_{2} \mathrm{O}$ and $\mathrm{CH}_{4}$ using EC, REA and wavelet covariance agreed reasonably well. However the agree ment was better for the $\mathrm{H}_{2} \mathrm{O}$ flux (EC $v s$ REA, $\mathrm{R}^{2}=0.86$; EC $v s$ wavelet
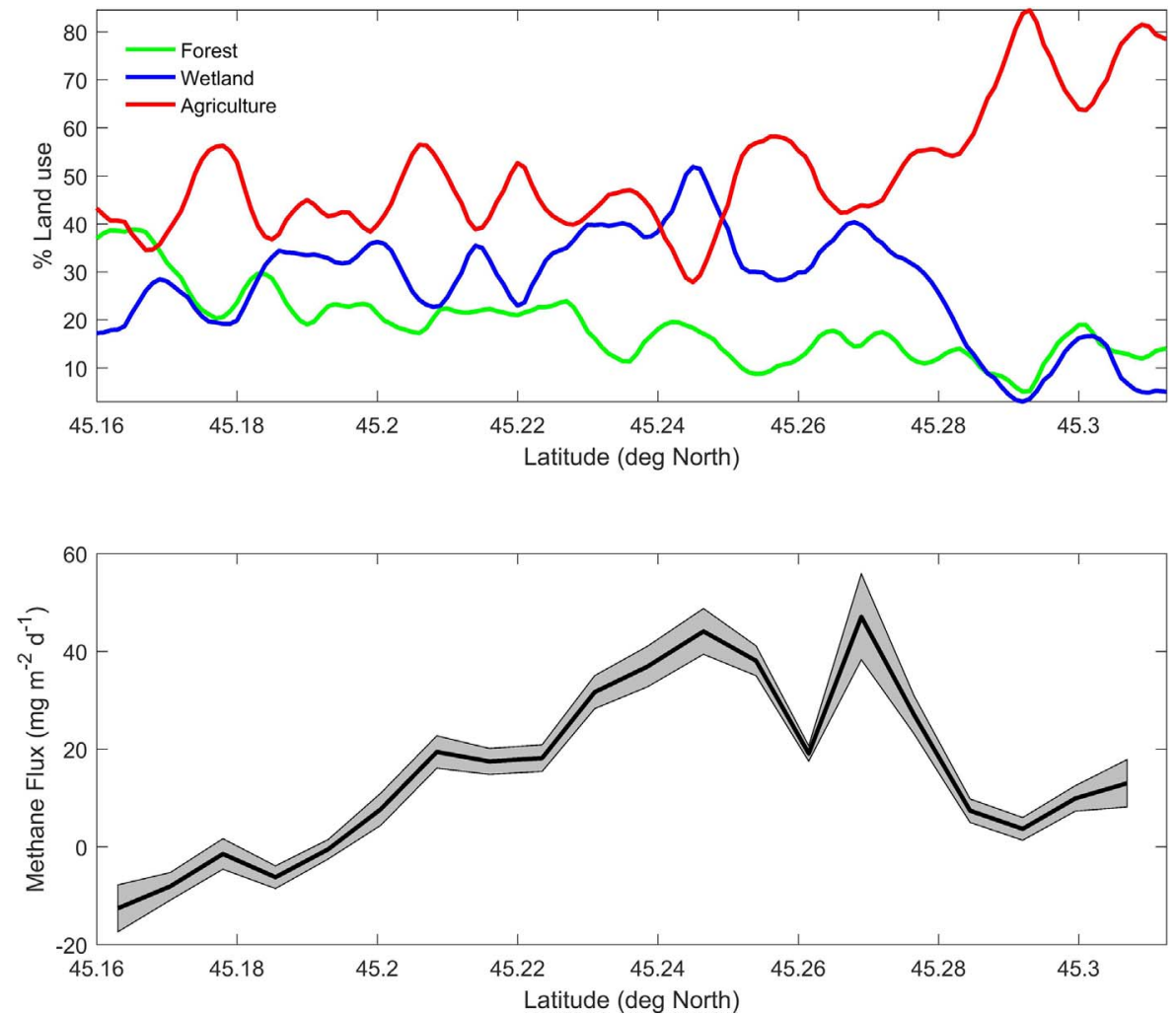

Fig. 7. Land use contributions to the flux footprint (upper panel) for flight 10 transect $\mathrm{F}$ and $1 \mathrm{~km}$ spatially resolved $\mathrm{CH}_{4}$ flux (lower panel). Shaded grey area represents $\pm 1 \mathrm{SE}$, based on $\mathrm{n}=7$ repeated runs. Average surface temperature was $25.6^{\circ} \mathrm{C}$. 


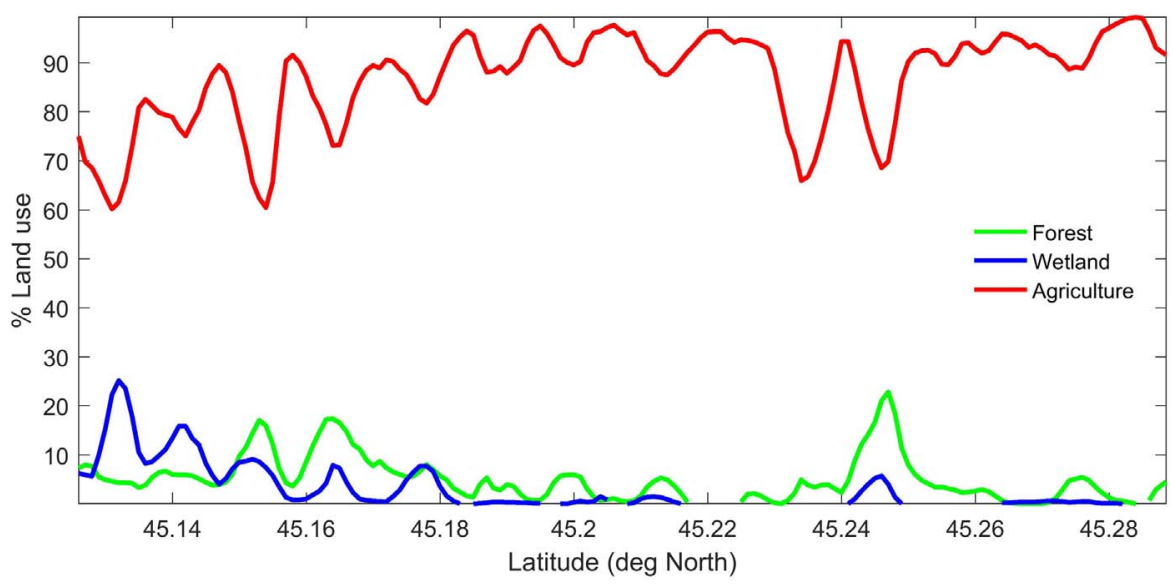

Fig. 8. Land use contributions to the flux footprint (upper panel) for flight 1 transect $\mathrm{E}$ and $1 \mathrm{~km}$ spatially resolved $\mathrm{CH}_{4}$ flux (lower panel) based on the top-down measurements and bottom-up inventory calculation. Shaded grey area represents $\pm 1 \mathrm{SE}$, based on $\mathrm{n}=3$ repeated runs.

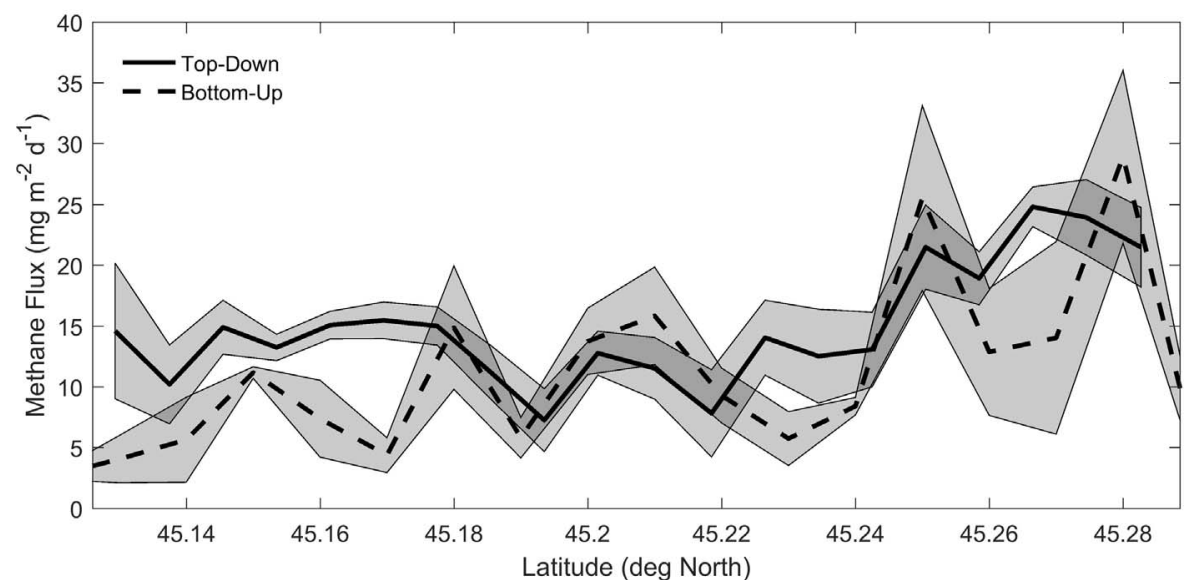

covariance, $\mathrm{R}^{2}=0.97$ ) than for the $\mathrm{CH}_{4}$ flux (EC $v s$. REA, $\mathrm{R}^{2}=0.54$, EC $v s$ wavelet covariance, $\left.R^{2}=0.85\right)$. The main reason for the weaker agreement for $\mathrm{CH}_{4}$ is that the fluctuations in $\mathrm{CH}_{4}$ concentration with respect to the mean concentration are much smaller than for water vapor. For water vapor the $A$ coefficient, calculated as the slope of $\mathrm{FH}_{2} \mathrm{O}_{E C}$ and $\mathrm{FH}_{2} \mathrm{O}_{\mathrm{REA}}$ is 0.49 . The value of 0.45 which was found for $\mathrm{CH}_{4}$ can be considered to be similar to the water vapor value taking in consideration the scatter in the data (Fig. 2, Table 2).

\subsection{Top down vs. bottom up estimates of $\mathrm{CH}_{4}$ emissions}

Regional and national $\mathrm{CH}_{4}$ emissions inventory, as needed for UNFCCC reporting, are typically estimated using a bottom up approach, where activity data collected at either the regional or national scale are multiplied by emission factors in order to estimate $\mathrm{CH}_{4}$ emissions. The accuracy of the estimate is therefore dependent upon the collection of reliable activity data, representative emission factors and a complete accounting of all sources of $\mathrm{CH}_{4}$. The top down approach, based on aircraft flux measurements, to verify inventories of trace gas emissions at a regional scale provides an attractive comparison, as it is in dependent of the assumptions necessary in a bottom up approach.

In this study, we employed a georeferenced database of known dairy farms in the study region. Since detailed, geolocated information re garding other farm types was not available for the study area; we tried to overcome this limitation through a detailed search using satellite images to identify other farms, and to estimate their $\mathrm{CH}_{4}$ emissions.

Similar to our study, Wratt et al. (2001) recognized that the timing of aircraft based $\mathrm{CH}_{4}$ flux measurements might bias the results due to the diurnal cycle of $\mathrm{CH}_{4}$ emissions associated with enteric fermentation. They applied a $20 \%$ correction factor to the bottom up approach in order to compensate for this bias. We did not apply a similar correction factor to our estimates, as studies by Kinsman et al. (1995) and van Haarlem et al. (2008) suggest that for cattle, $\mathrm{CH}_{4}$ emissions peak $12 \mathrm{~h}$ after feeding, but a midday decrease in the rate of $\mathrm{CH}_{4}$ production by ruminants means that during the aircraft measurements, the rate of emissions is likely only about $5 \%$ greater than the daily average. Dairy cattle in Ontario, Canada are primarily kept in barns, and their manure is typically managed as a liquid. Manure temperature is a primary control on the rate of $\mathrm{CH}_{4}$ emissions from liquid manure storage (Massé et al., 2003). Therefore, the temporal timing of measurements may affect the comparison between bottom up and top down estimates of emissions. Mean annual temperature reported at the Ottawa Airport, $50 \mathrm{~km}$ north east of the flight transects is $6{ }^{\circ} \mathrm{C}$, whereas average air temperature during the measurement campaign (April 8 May 12) was $8.5^{\circ} \mathrm{C}$ and in flight average air temperature ranged from 2.0 to $21.4^{\circ} \mathrm{C}$. Given the timing of the measurement campaign prior to green up of local fields, it is likely that manure storage tanks in the area were at, or nearly at capacity. These two factors should result in greater $\mathrm{CH}_{4}$ emissions from manure management systems as compared to the an nual average. We accounted for this difference in $\mathrm{CH}_{4}$ emissions in the bottom up approach by adopting emission factors taken from on farm measurements that are specific to the region and coinciding with the same time of year as the measurement timing (VanderZaag et al., 2014).

Top down estimates of $\mathrm{CH}_{4}$ emissions have been previously re ported for the greater Los Angeles area (Hsu et al., 2010), the greater Indianapolis area (Mays et al., 2009), a pastoral farming region of New Zealand (Wratt et al., 2001), an oil and gas producing region of the United States (Karion et al., 2013) and a wetland area of Scotland (Choularton et al., 1995). Hsu et al. (2010) estimated regional $\mathrm{CH}_{4}$ 
emissions using fixed point source measurements of both carbon monoxide and $\mathrm{CH}_{4}$, whereas Mays et al. (2009) estimated $\mathrm{CH}_{4}$ emis sions using an aircraft based sampling procedure and corresponding meteorological variables. Both Mays et al. (2009) and Hsu et al. (2010) compared emissions estimates for top down and bottom up approaches, and both report that the top down approach results in emission esti mates that are approximately one third greater than the bottom up approach. Hsu et al. (2010) hypothesized that this may represent un accounted sources in the bottom up approach, however, the bottom up estimates fall within the top down measurement uncertainty. Similarly, because of measurement uncertainty, the top down and bottom up es timates of Mays et al. (2009) are not statistically different from each other. Wratt et al. (2001) conducted a top down analysis of $\mathrm{CH}_{4}$ emissions using a mass balance approach and aircraft collected air samples from a pastoral farming region in New Zealand. They com pared top down results with bottom up estimates based on animal in ventories and $\mathrm{CH}_{4}$ emission factors and found that the top down esti mates were larger than the bottom up. Therefore, it is a general observation that top down estimates of emissions exceed bottom up estimates, and this study is no exception, finding that observed EC, REA and wavelet covariance top down measurements of $\mathrm{CH}_{4}$ emissions (EC: $17 \pm 4 \mathrm{mg} \mathrm{m}^{-2} \mathrm{~d}^{-1}$ ) all significantly exceeded bottom up estimates $\left(8 \pm 1 \mathrm{mg} \mathrm{m}^{-2} \mathrm{~d}^{-1}\right)$. However, the inclusion of wetlands as a source of $\mathrm{CH}_{4}$ would reduce this difference substantially.

\subsection{Sources of errors in the comparison between bottom up and top down $\mathrm{CH}_{4}$ emission estimates}

There are several potential sources of errors in the comparison be tween top down and bottom up $\mathrm{CH}_{4}$ emissions estimates. For example: 1) Since the flux measurements were performed at approximately $0.1 \mathrm{z}_{\mathrm{i}}$, one could expect to slightly underestimate the surface fluxes due to flux divergence with height (Betts et al., 1990). However, for both flights 8 and 10, flux measurements were carried out at three altitudes ranging from 148 to $273 \mathrm{~m}$ agl. No significant trend in height could be detected for the $\mathrm{CH}_{4}$ flux. We can then assume that the $\mathrm{CH}_{4}$ flux measurements are a good approximation of the $\mathrm{CH}_{4}$ emissions at the surface. 2) In the footprint analysis, we made a simplifying assumption that barns re present distinct, point sources of $\mathrm{CH}_{4}$. This may be true for manure management systems, swine and poultry which are typically con tinuously housed, however cattle spend a variable amount of time grazing, meaning that they no longer represent a point source. How ever, given the timing of the measurements prior to green up of the majority of fields, it is unlikely that cattle were grazing in significant number. 3) Annualized estimates of emissions are presented based on measurements taken only in spring. Although we anticipate little sea sonality in emissions from enteric fermentation (VanderZaag et al., 2014), this is likely not true for emissions from manure management, and unmanaged emissions from wetlands. 4) The need for correcting the fast response $\mathrm{CH}_{4}$ analyzer for pressure fluctuations in the sampling cell likely increased the variability of the flux estimates using EC and wavelet covariance. We were not certain if the pressure correction performed on the fast response $\mathrm{CH}_{4}$ analyzer based on one run was applicable to all runs. Use of the REA technique, which avoided that problem, was extremely useful to confirm that the pressure correction that we did was adequate.

\subsection{Considerations for future research}

This study demonstrates that low altitude aircraft based flux tech nology can now be used to quantify the spatial variability in $\mathrm{CH}_{4}$ emissions at a wide range of scales. Using the unmixing technique de scribed by Chen et al. (1999) and accurate land use information, such measurements could be used to better resolve $\mathrm{CH}_{4}$ emissions from managed and unmanaged sources which is essential when we try to allocate GHG emissions to various sectors. In order to ensure high quality measurements and a more accurate evaluation of agricultural $\mathrm{CH}_{4}$ inventory estimates the following recommendations for future studies are provided:

1. Choice of study location: Flight transects should be chosen with great care to maximize flux footprint overlap with the target source of emissions. We find that an area greater than $80 \%$ of the target land use is desirable, but it was challenging to achieve in the study area that we selected. High resolution satellite images should be consulted to avoid flux footprint overlap with several $\mathrm{CH}_{4}$ sources. Confounding $\mathrm{CH}_{4}$ sources were found to include wetlands, farm biodigestion of organic material, municipal water treatment, and municipal composting of organic material.

2. Choice of $\mathrm{CH}_{4}$ analyzer: Specifications of a desirable $\mathrm{CH}_{4}$ analyzer include: (i) stability, (ii) fast response rate, (iii) high accuracy, (iv) high precision, and (v) insensitivity to aircraft motion. In this study, the fast response CRDS was found to meet specifications (i) through (iv). However, the impact of aircraft motion on pressure fluctuations in the sampling cell needs to be reduced. A Parker valve was used in the G2301 $\mathrm{f}$ and according to the manufacturer (David Kim Hak, Picarro Inc.) a Clippard valve, which is less sensitive to vibration for flight deployment would have resulted in less pressure fluctuations in the sampling cell and less need to make the pressure correction and less variable $\mathrm{CH}_{4}$ flux measurements.

3. Measurement period: A potential limitation of this study is the lack of seasonal coverage. Since inventories are presented on an annual basis, yet measurements are only taken in spring, it could be ben eficial to add more campaigns to extend the measurements to other seasons, but we do not think that it would result in a different conclusion.

\section{Conclusions}

Using aircraft based systems, comparable measurements of $\mathrm{CH}_{4}$ emissions were obtained at a high spatial resolution using the EC, wavelet covariance, and the REA techniques. We showed that the $\mathrm{CH}_{4}$ emission estimates, from an agricultural region, based on bottom up IPCC Tier II emission factors, agreed reasonably well with the aircraft flux measurements when the land use type was mainly agricultural. We demonstrated that validating $\mathrm{CH}_{4}$ emissions inventory from agricultural sources using aircraft flux measurements is challenging because of the presence of other $\mathrm{CH}_{4}$ sources such as wetlands and anthropogenic sources such as waste treatment plants, biodigesters, etc. The tem perature dependency of $\mathrm{CH}_{4}$ emissions from wetlands helped confirm the large contribution of wetlands to $\mathrm{CH}_{4}$ emissions.

\section{Acknowledgements}

We thank the staff of the Aerospace division of the National Research Council of Canada for collecting the aircraft based data. We also thank the Dairy Farmers of Ontario for providing a georeferenced database of dairy quota in our study region. We thank Ian Jarvis for providing some of the information on the location of livestock in the region based on a windshield survey. We are grateful for the loan of the Picarro G1301 from Environment Canada, and the loan of the Picarro G2301 from the National Oceanic and Atmospheric Administration. We also acknowledge the National Carbon and Greenhouse Gas Accounting and Verification System (NCGAVS) of Agriculture and Agri Food Canada for financially supporting the aircraft flights. Part of the ana lysis package used in this study is based upon work supported by the National Science Foundation under the grant DBI 0752017. The National Ecological Observatory Network is a project sponsored by the National Science Foundation and managed under cooperative agree ment by Battelle Ecology, Inc. We thank two anonymous reviewers for their comments and suggesions, which have helped to improve this manuscript. 


\section{References}

Attié, J.-L., Durand, P., 2003. Conditional wavelet technique applied to aircraft data measured in the thermal internal boundary layer during sea-breeze events. Boundary Layer Meteorol. 106 (3), 359-382.

Beauchemin, K.A., McGinn, S.M., 2005. Methane emissions from feedlot cattle fed barley or corn diets. J. Anim. Sci. 83, 653-661.

Beauchemin, K.A., McGinn, S.M., 2006. Enteric methane emissions from growing beef cattle as affected by diet and level of intake. Can. J. Anim. Sci. 86 (3), 401-408.

Bergamaschi, P., et al., 2010. Inverse modeling of european CH4 emissions 2001-2006. J. Geophys. Res. Atmos. 115, D22309.

Betts, A.K., Desjardins, R.L., MacPherson, J.I., Kelly, R.D., 1990. Boundary-layer heat and moisture budgets from FIFE. Boundary Layer Meteorol. 50, 109-138.

Businger, J.A., Oncley, S.P., 1990. Flux measurement with conditional sampling. J. Atmos. Oceanic Technol. 7 (2), 349-352.

Chen, J.M., Leblanc, S.G., Cihlar, J., Desjardins, R.L., MacPherson, J.I., 1999. Extending aircraft- and tower-based $\mathrm{CO}_{2}$ flux measurements ot a boreal region using a landsat thematic mapper land cover map. J. Geophys. Res. 104 (D14), 16859-16877.

Chen, H., et al., 2010. High-accuracy continuous airborne measurements of greenhouse gases ( $\mathrm{CO} 2$ and $\mathrm{CH} 4)$ using the cavity ring-down spectroscopy (CRDS) technique. Atmos. Meas. Tech. 3, 375-386.

Choularton, T.W., et al., 1995. Trace gas flux measurements at the landscape scale using boundary-layer budgets. Philos. Trans. R. Soc. A 351, 357-369.

Cressot, C., et al., 2014. On the consistency between global and regional methane emissions inferred from SCIAMACHY, TANSO-FTS, IASI and surface measurements. Atmos. Chem. Phys. 14, 577-592.

Denmead, O.T., et al., 2000. Verifying inventory predictions of animal methane emissions with meteorological measurements. Boundary Layer Meteorol. 96, 187-209.

Desjardins, R.L., MacPherson, J.I., 1991. Water vapour flux measurements from aircraft In: Schmugge, T., Andre, J.C. (Eds.), Land Surface Evaporation - Measurement and Parameterisation. Springer-Verlag Ltd., New York, pp. 245-260.

Desjardins, R.L., Brach, E.J., Alvo, P., Schuepp, P.H., 1982. Aircraft monitoring of surface carbon dioxide exchange. Science 216 (4547), 733-735

Desjardins, R.L., MacPherson, I., Schuepp, P.H., 2000. Aircraft-based flux sampling strategies. In: Meyers, R.A. (Ed.), Encyclopedia of Analytical Chemistry. John Wiley and Sons Ltd., Chichester, pp. 3573-3588.

Desjardins, R.L., et al., 2010. Multiscale estimates of $\mathrm{N}_{2} \mathrm{O}$ emissions from agricultural lands. Agric. For. Meteorol. 150, 817-824.

Desjardins, R.L., 1972. A Study of Carbon Dioxide and Sensible Heat Fluxes Using the Eddy Correlation Technique. Cornell University, Ithaca, pp. 189 Ph.D. Thesis.

Environment Canada, 2015a. National Inventory Report, 1990-2013. Greenhouse Gas Sources and Sinks in Canada. Part 2. Environment Canada, Gatineau, Quebec, pp 226.

Environment Canada, 2015b. National Inventory Report. Greenhouse Gas Sources and Sinks in Canada - Part 3. Environment Canada, Pollutant Inventories and Reporting Division, Gatineau, QC, pp. 85.

Felber, R., Münger, A., Neftel, A., Ammann, C., 2015. Eddy covariance methane flux measurements over a grazed pasture: effect of cows as moving point sources. Biogeosciences 12, 3925-3940.

Flesch, T.K., Vergé, X.P.C., Desjardins, R.L., Worth, D.E., 2013. Methane emissions from a swine manure tank in western Canada. Can. J. Anim. Sci. 93 (1), 159-169.

Gao, Z., Desjardins, R.L., Flesch, T.K., 2010. Assessment of the uncertainty of using an inverse dispersion technique to measure methane emissions from animals in a barn and in a small pen. Atmos. Environ. 44 (26), 3128-3134.

Hsu, Y.-K., et al., 2010. Methane emissions inventory verification in southern California. Atmos. Environ. 44, 1-7.

IPCC, 2006. Volume 4 agriculture, forestry and other land use. chapter 10: emissions from livestock and manure management. In: Eggleston, S., Buendia, L., Miwa, K., Ngara, T., Tanabe, K. (Eds.), 2006 IPCC Guidelines for National Greenhouse Gas Inventories. Institute for Global Environmental Strategies, Hayama, Japan.

IPCC, 2013. Climate Change 2013: The Physical Science Basis. Contribution of Working Group I to the Fifth Assessment Report of the Intergovernmental Panel on Climate Change. Cambridge University Press, Cambridge, UK and New York, NY USA

Judd, M.J., et al., 1999. Net methane emissions from grazing sheep. Glob. Change Biol. 5, 647-657.

Karimi-Zindashty, Y., et al., 2012. Sources of uncertainty in the IPCC tier 2 Canadian livestock model. J. Agric. Sci. 150, 556-569.

Karion, A., et al., 2013. Methane emissions estimate from airborne measurements over a western United States natural gas field. Geophys. Res. Lett. 40, 1-5.

Kinsman, R., Sauer, F.D., Jackson, H.A., Wolynetz, M.S., 1995. Methane and carbon dioxide emissions from dairy cows in full lactation over a six-month period. J. Dairy Sci. 78, 2760-2766.

Kirschke, S., et al., 2013. Three decades of global methane sources and sinks. Nat. Geosci. 6 (10), 813-823.

Kljun, N., Rotach, M.W., Schmid, H.P., 2002. A three-dimensional backward Lagrangian gootprint model for a wide range of boundary-layer stratifications. Boundary-Layer Meteorology 103, 205-226.

Kljun, N., Calanca, P., Rotach, M.W., Schmid, H.P., 2004. A simple parameterisation for flux footprint predictions. Boundary Layer Meteorol. 112 (3), 503-523.

Kort, E.A., et al., 2008. Emissions of CH4 and N2O over the United States and Canada based on a receptor-oriented modeling framework and COBRA-NA atmospheric observations. Geophys. Res. Lett. 35, L18808.
Lessard, R., et al., 1994. Methane and carbon dioxide fluxes from poorly drained adjacent cultivated and forest sites. Can. J. Soil Sci. 74, 139-146.

MacPherson, I.J., Desjardins, R.L., 1991. Airborne tests of flux measurement by the relaxed eddy accumulation technique. 7th Symposium on Meteorological Observation and Instrumentation. American Meteorological Society, New Orleans, LA, pp. 6-11.

Mahrt, L., Howell, J.F., 1994. The influence of coherent structures and microfronts on scaling laws using global and local transforms. J. Fluid Mech. 260, 247-270.

Manning, A.J., Ryall, D.B., Derwent, R.G., Simmonds, P.G., O'Doherty, S., 2011. Estimating UK methane and nitrous oxide emissions from 1990 to 2007 using an inversion modelling approach. J. Geophys. Res. Atmos. 116, D02305.

Massé, D., Croteau, F., Patni, N.K., Masse, L., 2003. Methane emissions from dairy cow and swine manure slurries stored at $10{ }^{\circ} \mathrm{C}$ and $15{ }^{\circ} \mathrm{C}$. Can. Biosyst. Eng. 45, 6.1-6.6.

Mauder, M., Desjardins, R.L., MacPherson, J.I., 2007. Scale analysis of airborne flux measurements over heterogeneous terrain in a boreal ecosystem. J. Geophys. Res. 112, D13112.

Mauder, M., Desjardins, R.L., MacPherson, I.J., 2008. Creating surface flux maps from airborne measurements: application to the Mackenzie area GEWEX study MAGS 1999. Boundary Layer Meteorol. 129, 431-450.

Mays, K.L., et al., 2009. Aircraft-based measurements of the carbon footprint of Indianapolis. Environ. Sci. Technol. 43, 7816-7823.

McGinn, S.M., Beauchemin, K.A., Flesch, T.K., Coates, T., 2009. Performance of a dispersion model to estimate methane loss from cattle in pens. J. Environ. Qual. 38, 1796-1802.

Metzger, S., et al., 2013. Spatially explicit regionalization of airborne flux measurements using environmental response functions. Biogeosciences 10, 2193-2217.

Miller, J.B., et al., 2012. Linking emissions of fossil fuel $\mathrm{CO}_{2}$ and other anthropogenic trace gases using atmospheric ${ }^{14} \mathrm{CO}_{2}$. J. Geophys. Res. 117, D08302.

Miller, S.M., et al., 2013. Anthropogenic emissions of methane in the United States. Proc. Natl. Acad. Sci. U. S. A. 110 (50), 20018-20022.

Moore, T.R., Knowles, R., 1990. Methane emissions from fen, bog and swamp peatlands in Quebec. Biogeochemistry 11, 45-61.

Moore, T.R., et al., 2011. A multi-year record of methane flux at the Mer Bleue bog, Southern Ontario. Ecosystems 14, 646-657.

Moravek, A., Trebs, I., Foken, T., 2013. Effect of imprecise lag time and high frequency attenuation on surface-atmosphere exchange determined with the relaxed eddy accumulation method. J. Geophys. Res. Atmos. 118. http://dx.doi.org/10.1002/jgrd. 50763.

Ontario Ministry of Natural Resources, 2008. In: Smyth, I. (Ed.), Southern Ontario Land Resource Information System Version 1.2. Ontario Ministry of Natural Resources, Peterborough, Ontario

Pattey, E., Desjardins, R.L., Rochette, P., 1993. Accuracy of the relaxed eddy-accumulation technique, evaluated using $\mathrm{CO}_{2}$ flux measurements. Boundary Layer Meteorol. 66, 341-355.

Pattey, E., et al., 2007. Tools for quantifying $\mathrm{N}_{2} \mathrm{O}$ emissions from agroecosystems. Agric. For. Meteorol. 142, 103-119.

R Development Core Team, 2005. A Language and Environment for Statistical Computing. R Foundation for Statistical Computing, Vienna Austria.

Sauer, F.D., et al., 1998. Methane output and lactation response in Holstein cattle with monensin or unsaturated fat added to the diet. J. Anim. Sci. 76 (3), 906-914.

Statistics Canada, 2016. 2011 Census of Agriculture, Farm and Farm Operator Data. Statistics Canada.

Stull, R.B., 1988. An Introduction to Boundary Layer Meteorology. Kluwer Academic Publishers, Dordrecht.

Thompson, R.L., et al., 2017. Methane fluxes in the high northern latitudes for 2005-2013 estimated using a Bayesian atmospheric inversion. Atmos. Chem. Phys. 17, 3553-3572.

Torrence, C., Compo, G.P., 1998. A practical guide to wavelet analysis. Bull. Am. Meteorol. Soc. 79, 61-78.

Turetsky, M.R., et al., 2014. A synthesis of methane emissions form 71 northern, temperate, and subtropical wetlands. Glob. Change Biol. 20, 2183-2197.

Turner, A.J., et al., 2015. Estimating global and North American methane emissions with high spatial resolution using GOSAT satellite data. Atmos. Chem. Phys. 15, 7049-7069.

van Haarlem, R., Desjardins, R.L., Gao, Z., Flesch, T.K., Li, X., 2008. Methane and ammonia emissions from a beef feedlot in western Canada for a twelve-day period in the fall. Can. J. Anim. Sci. 88, 641-649.

VanderZaag, A.C., Flesch, T.K., Desjardins, R.L., Baldé, H., Wright, T., 2014. Methane emissions from two dairy farms: seasonal and manuremanagement effects. Agric. For. Meteorol. 194, 259-267.

Veefkind, J.P., et al., 2012. TROPOMI on the ESA Sentinel-5 Precursor: a GMES mission for global observations of the atmospheric composition for climate, air quality and ozone layer applications. Remote Sens. Environ. 120, 70-83.

Vergé, X.P.C., Dyer, J.A., Desjardins, R.L., Worth, D., 2007. Greenhouse gas emissions from the Canadian dairy industry in 2001. Agric. Syst. 94 (3), 683-693.

Vickers, D., Mahrt, L., 1997. Quality control and flux sampling problems for tower and aircraft data. J. Atmos. Oceanic Technol. 14, 512-526.

Vogel, F.R., et al., 2012. Regional non-CO2 greenhouse gas fluxes inferred from atmospheric measurements in Ontario, Canada. J. Integr. Environ. Sci. 9, 41-55.

Wratt, D.S., et al., 2001. Estimating regional methane emissions from agriculture using aircraft measurements of concentration profiles. Atmos. Environ. 35, 497-508.

Zhao, C., et al., 2009. Atmospheric inverse estimates of methane emissions from Central California. J. Geophys. Res. Atmos. 114, D16302. 


\section{Repository KITopen}

Dies ist ein Postprint/begutachtetes Manuskript.

Empfohlene Zitierung:

Desjardins, R. L.; Worth, D. E.; Pattey, E.; VanderZaag, A.; Srinivasan, R.; Mauder, M.;

Worthy, D. E. J.; Sweeney, C. O.; Metzger, S.

The challenge of reconciling bottom-up agricultural methane emissions inventories with topdown measurements.

2018. Agricultural and forest meteorology, 248.

doi: $10.554 / I R / 1000075357$

Zitierung der Originalveröffentlichung:

Desjardins, R. L.; Worth, D. E.; Pattey, E.; VanderZaag, A.; Srinivasan, R.; Mauder, M.;

Worthy, D. E. J.; Sweeney, C. O.; Metzger, S.

The challenge of reconciling bottom-up agricultural methane emissions inventories with topdown measurements.

2018. Agricultural and forest meteorology, 248, 48-59. doi:10.1016/j.agrformet.2017.09.003 